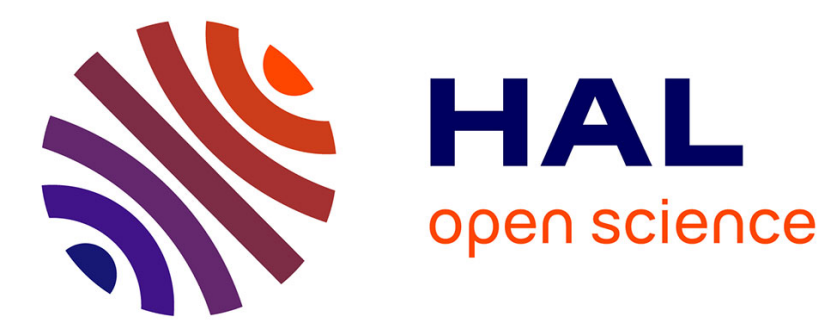

\title{
The Costs and Benefits of Duty-Free, Quota-Free Market Access for Poor Countries: Who and What Matters
}

\author{
Antoine Bouët, David Laborde, Elisa Dienesch, Kimberly Elliot
}

\section{To cite this version:}

Antoine Bouët, David Laborde, Elisa Dienesch, Kimberly Elliot. The Costs and Benefits of Duty-Free, Quota-Free Market Access for Poor Countries: Who and What Matters. 2010. hal-01885164

\section{HAL Id: hal-01885164 \\ https://hal-univ-pau.archives-ouvertes.fr/hal-01885164}

Preprint submitted on 1 Oct 2018

HAL is a multi-disciplinary open access archive for the deposit and dissemination of scientific research documents, whether they are published or not. The documents may come from teaching and research institutions in France or abroad, or from public or private research centers.
L'archive ouverte pluridisciplinaire HAL, est destinée au dépôt et à la diffusion de documents scientifiques de niveau recherche, publiés ou non, émanant des établissements d'enseignement et de recherche français ou étrangers, des laboratoires publics ou privés. 


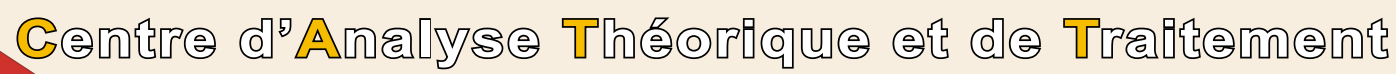

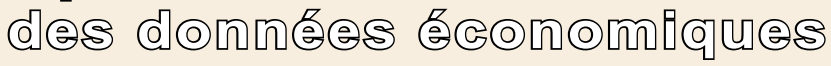

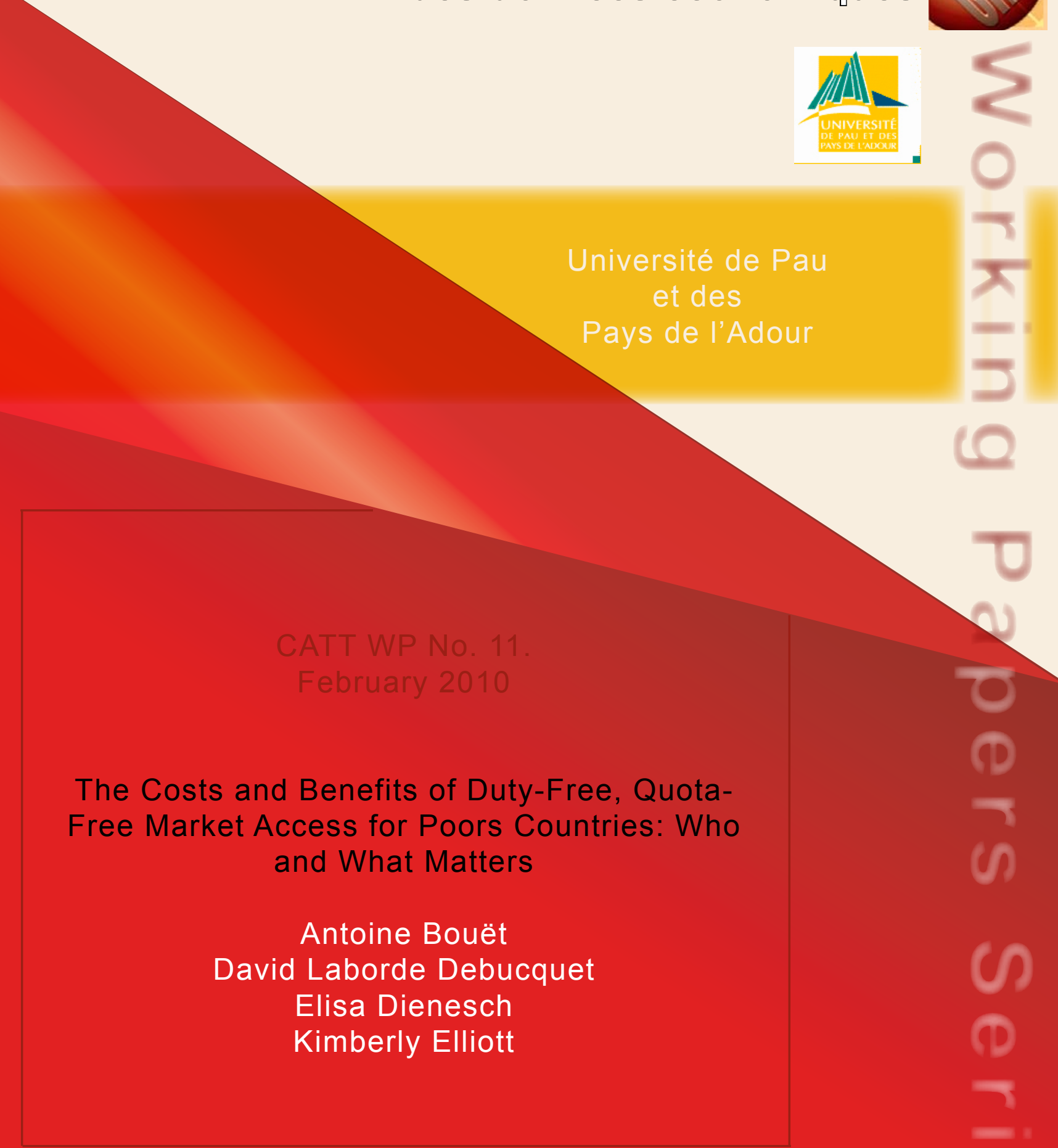




\title{
THE COSTS AND BENEFITS OF DUTY-FREE, QUOTA-FREE MARKET ACCESS FOR POOR COUNTRIES: WHO AND WHAT MATTERS
}

\author{
Antoine Bouët, \\ Senior Research Fellow, International Food Policy Research Institute (IFPRI), \\ and CATT, UPPA \\ UFR Droit, Economie, Gestion \\ Av Doyen Poplawski - BP1633 Pau cedex \\ Email : a.bouet@cgiar.org \\ David Laborde Debucquet \\ Research Fellow, International Food Policy Research Institute (IFPRI), \\ 2033 K St., NW \\ Washington, DC, 20006-1002 \\ Email : d.laborde@cgiar.org \\ Elisa Dienesch, \\ CATT, UPPA \\ UFR Droit, Economie, Gestion \\ Av Doyen Poplawski - BP1633 Pau cedex \\ Email : elisa.dienesch@gmail.com \\ Kimberly Elliott, \\ Senior Fellow, Center for Global Development (CGD) \\ 1800 Massachusetts Ave. NW \\ Washington DC 20036 \\ Email: kelliott@cgdev.org
}

\begin{abstract}
This paper examines the potential benefits and costs of providing duty-free-quotafree market access to the least-developed-countries (LDCs), and the effects of extending eligibility to other small and poor countries. Using the MIRAGE computable general equilibrium model, it assesses the impact of scenarios involving different levels of coverage for products, recipient countries, and preference-giving countries on participating countries, as well as competing developing countries that are excluded. The main goal of this paper is to highlight the role that rich and emerging countries could play in helping poor countries to improve their trade performance and to assess the distribution of costs and benefits for developing countries and whether the potential costs for domestic producers are in line with political feasibility in preference-giving countries.
\end{abstract}

JEL Classifications: D58; F13; F17;

Key Words: CGE modeling, trade policy, duty-free market access, technical barriers to trade, preference erosion. 


\section{Introduction}

The globalization surge of the past three decades mostly missed the poorest countries in the world. While other developing countries were able to ride the wave, the share of today's least developed countries (LDCs) in global exports fell by two-thirds from 1970 to 2000, twice as much as the fall in their share of global income. ${ }^{1}$ In broad terms, there are two principal sources of the LDCs' poor export performance: severe supply-side challenges, resulting from a lack of sound institutions and policies, inadequate infrastructure, and a paucity of physical and human capital; and implicit discrimination against their exports in rich-country trade policies. Progress is being made in a number of countries in addressing the supply-side challenges, but these problems will not be solved easily or quickly. The second source of poor export performance in poor countries should be more amenable to reform, as it requires only that richer countries open their markets to countries accounting for a tiny share of global trade. Opening markets for LDC exports is now even more important and more urgent as a result of the global financial crisis and the increased demand for trade protection around the world.

The high-income members of the Organization for Economic Cooperation and Development (OECD), and increasingly advanced developing countries as well, provide preferential market access for developing countries. But even the more generous programs for LDCs often contain exceptions and the exceptions are usually concentrated in a narrow range of products where LDCs have comparative advantage, especially agricultural commodities (often sugar, rice, meat, and dairy) and labor-intensive manufactures, such as textiles, apparel, and footwear. The effects of these politically-driven exclusions are further magnified by the structural weaknesses in the economies of LDCs, which are generally not very diversified. Thus, even a small number of product exclusions can rob preference programs of much of the potential benefit. In addition to the remaining formal barriers, preferential arrangements have rules of origin that restrict international sourcing of inputs and that is an acute concern in poorer countries with a high degree of specialization in the manufacturing sector, and limited ability to create the backward and forward linkages required by many origin regimes. ${ }^{2}$

To boost LDC engagement in global markets as a tool of poverty reduction, UN members agreed in the 2000 Millennium Declaration that developed countries should provide duty-free, quotafree (DFQF) market access for LDCs. That Millennium Development Goal (MDG) was reaffirmed at the World Trade Organization (WTO) ministerial in Hong Kong in 2005, except that U.S. negotiators insisted on limiting it to 97 percent of tariff lines. At the same time, the communiqué also called on developing countries "in a position to do so" to provide expanded preferential access for LDCs.

This study assesses four broad questions around improved market access for poor countries:

\footnotetext{
${ }^{1}$ Data is for today's list of LDCs (because the list changed over time) and is from the United Nations Comtrade database and the International Monetary Fund's International Financial Statistics.

${ }^{2}$ In assessing the potential to expand poor-country exports, it is important to keep in mind that administrative and regulatory barriers also arise outside the preference programs themselves. Most notably for some LDCs in Africa, sanitary and phytosanitary standards to protect human, plant, and animal safety frequently block agricultural exports because many poor countries lack the capacity to certify compliance.
} 
- How much would LDCs gain from 100 percent versus 97 percent DFQF market access in OECD markets?

- How would the distribution of gains and losses change if eligibility for DFQF access were extended to additional small and poor countries?

- How much would LDC gains rise if Brazil, China, and India also provide full market access?

- What would be the effect of improved access on producers in preference-giving countries?

Previous analyses have assessed the impact of such preferential agreements granted to LDCs. lanchovichina, Mattoo and Olarreaga (2001) use the GTAP model (Hertel, 1997) and the fourth version of the GTAP database (1995) to measure the gains and losses for a Sub-Saharan Africa countries' group (the 37 poorest countries aggregated together) if they receive DFQF market access from the Quad countries (Canada, European Union, the United States and Japan). Bora, Cernat and Turrini (2002) worked on simulating the elimination of all tariff and non tariff barriers imposed against LDCs in order to confirm the benefits for LDCs of the EBA initiative and underline the potential impact of a coordinated action of Quad countries. They showed that this larger preferential initiative provides ten times the welfare gains of the EBA alone. They conduct their analysis on the basis of a newer GTAP database than lanchovichina, Mattoo and Olarreaga. Thanks to a higher level of disaggregation in the more recent database, authors are able to highlight the importance of sensitive sectors such as rice, sugar or wearing apparel in the improvement of LDCs' market access, including both African and Asian countries. All those studies show the potential benefits for preference-receiving LDCs, and insignificant losses for preference-giving countries imports from LDCs are such a small share of imports and consumption. Finally, Vanzetti and Peters (2009) focus on the role of sensitive products and the gains from an extension of product coverage of preferential arrangements. All these studies emphasize the role of rich countries, especially the European Union in granting better market access for poorer countries at little or no cost to their own producers.

Four key things distinguish our work from these earlier studies. First, we go beyond the Quad countries and examine the potential impact when the large and fast-growing emerging markets also provide improved market access to the LDCs. Second, we pay close attention to the potential for preference erosion when existing preference arrangements are changed. Third, we use the MIRAGE model and the carefully compiled and detailed MacMAps-HS6 database. Finally, unlike previous analyses, we use an explicit political-economy welfare function to identify the sensitive products that are likely to be excluded if DFQF access is provided for only 97 percent of tariff lines, as proposed in Hong Kong. More ad hoc methods may underestimate the negative impact of such exclusions, as explained by Jean et al. (2010). The political economy model developed by Jean et al. (2010) assumes that governments optimize their objective function by choosing sensitive sectors that minimize the social cost. We employ this methodology to treat the small number of tariffs lines that are defined as sensitive in our scenarios with 97 percent tariff line coverage ${ }^{3}$. To preview the results, the analysis confirms the

\footnotetext{
${ }^{3}$ To see the detailed tariffs lines obtained by this procedure, please refer to the Annex Table 2
} 
conclusion from previous research that a DFQF initiative limiting product coverage to 97 percent of tariff lines provides very few benefits for LDCs. And, the gains from full access are multiplied if the large emerging markets join the initiative. But the evidence does not support two of the chief concerns about expanded preferential access for those countries. First, subSaharan Africa generally stands to gain, not lose, if OECD countries, including the United States, provide 100 percent DFQF market access for all LDCs; and other developing countries, such as Pakistan, do not suffer from preference erosion. Second, preference-giving countries do not suffer market disruption from removing exclusions for sensitive products, such as sugar or dairy. The adjustments are greater, however, if DFQF market access is extended to a broader group of small and poor countries.

Before explaining the methodology used in the paper, Box 1 presents key trade characteristics of $\mathrm{LDCs}^{4}$ that are useful in interpreting the results of our analysis

4. As will be explained in more detail, the reliability of the data regarding some of the LDCs means that some countries are included in more aggregated regions. Our aggregation choices are explained in the main text. 


\section{Box 1: Key factors in LDC trade performance}

\begin{tabular}{|c|c|c|c|c|}
\hline Country or region & Sectors $^{1}$ & 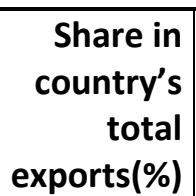 & $\begin{array}{r}\text { Relative } \\
\text { comparative } \\
\text { advantage }^{2}\end{array}$ & $\begin{array}{r}\text { Average } \\
\text { protection } \\
\text { faced }^{3}(\%)\end{array}$ \\
\hline \multirow{3}{*}{ Bangladesh } & Textiles & 35.7 & 12.6 & 13.8 \\
\hline & Wearing apparel & 30.3 & 12.2 & 12.9 \\
\hline & Leather & 4.6 & 4.6 & 13.8 \\
\hline \multirow{2}{*}{ Madagascar } & Foods products & 10.6 & 6.6 & 5.2 \\
\hline & Textiles & 8.9 & 3.1 & 1.5 \\
\hline \multirow{2}{*}{ Malawi } & Other crops & 24.9 & 64.9 & 52.3 \\
\hline & Coal, oil, gas & 16.8 & 2.1 & 3.9 \\
\hline \multirow{2}{*}{ Rest of Africa } & Other. mfd. products & 21.8 & 0.5 & 1.2 \\
\hline & Chemical products & 7.6 & 0.7 & 1.3 \\
\hline \multirow{3}{*}{ Rest of South East Asia } & Coal, oil, gas & 41.4 & 5.3 & 0.6 \\
\hline & Wearing apparel & 15.9 & 6.4 & 5.9 \\
\hline & Textiles & 11.3 & 4.0 & 7.8 \\
\hline \multirow{3}{*}{ Senegal } & Chemical products & 21.1 & 2.0 & 1.2 \\
\hline & Foods products & 14.7 & 9.1 & 24.9 \\
\hline & Other. mfd. products & 12.2 & 0.3 & 6.1 \\
\hline
\end{tabular}

\footnotetext{
${ }^{1}$ these are GTAP sectors
}

2

$$
R C A_{r i}=\frac{X_{r i}}{\sum_{j} X_{r j}} / \frac{\sum X_{s i}}{\sum_{j} \sum_{s} X_{s j}}
$$

with $r$ the reporter and $s$ its partners, $i(j)$ the sectors.

${ }^{3}$ OECD sectoral tariffs are weighted by the share of each partner in total exports.

The above table underscores that for many LDCs, comparative advantage and exports are relatively concentrated in a few sectors and in many cases (Bangladesh in textile and wearing apparel; Malawi in tobacco (other crops)) they face unusually high levels of protection.

The table below gives a further idea of the high degree of inter-industry specialization in many LDCs. The inter-industry specialization index (see footnote 4 for its construction) shows that all of them have high degrees of specialization in comparison with developed countries (around 0.20-0.25 for France, Germany, the US and even China 0.33). As reflected in Note 4, a high level of this index means that LDCs are dangerously specializing in few products, so their trade is dramatically affected by changing conditions in their export markets. 


\section{Box 1(cont.)}

Specialization and commodity dependence of LDC trade

\begin{tabular}{|c|c|c|c|c|}
\hline $\begin{array}{c}\text { DFQF } \\
\text { recipients } \\
\text { (LDCs) }\end{array}$ & $\begin{array}{l}\text { Specialization } \\
\text { index }\end{array}$ & Sectors & $\begin{array}{l}\text { Share in total } \\
\text { exports(\%) }\end{array}$ & $\begin{array}{c}\text { Relative } \\
\text { Comparative } \\
\text { advantage } \\
\end{array}$ \\
\hline \multirow{5}{*}{ Bangladesh } & \multirow{5}{*}{0.693} & Textiles & 35.733 & 12.550 \\
\hline & & Apparel & 30.329 & 12.199 \\
\hline & & Services & 12.764 & 1.226 \\
\hline & & Leather & 4.603 & 4.644 \\
\hline & & Foods products & 4.359 & 2.702 \\
\hline \multirow{5}{*}{ Ethiopia } & \multirow{5}{*}{0.727} & Transport & 18.061 & 4.120 \\
\hline & & Services & 17.914 & 1.721 \\
\hline & & Other crops & 12.657 & 32.947 \\
\hline & & Sugar & 9.287 & 60.082 \\
\hline & & Trade & 8.197 & 3.569 \\
\hline \multirow{5}{*}{ Madagascar } & \multirow{5}{*}{0.659} & Coal, oil, gas & 19.915 & 2.530 \\
\hline & & Sugar & 15.336 & 99.212 \\
\hline & & Foods products & 10.609 & 6.576 \\
\hline & & Transport & 9.107 & 2.078 \\
\hline & & Textiles & 8.890 & 3.122 \\
\hline \multirow{5}{*}{ Malawi } & \multirow{5}{*}{0.846} & Sugar & 42.192 & 272.961 \\
\hline & & Other crops & 24.915 & 64.855 \\
\hline & & Coal, oil, gas & 16.803 & 2.135 \\
\hline & & Other mfd. products & 2.514 & 0.052 \\
\hline & & Cotton, wool, silk & 2.227 & 5.833 \\
\hline \multirow{5}{*}{ Mozambique } & \multirow{5}{*}{0.674} & Metals & 51.946 & 18.640 \\
\hline & & Services & 20.284 & 1.948 \\
\hline & & Sugar & 5.152 & 33.328 \\
\hline & & Foods products & 4.627 & 2.868 \\
\hline & & Transport & 3.712 & 0.847 \\
\hline \multirow{5}{*}{$\begin{array}{l}\text { Rest of } \\
\text { Africa }\end{array}$} & \multirow{5}{*}{0.470} & Coal, oil, gas & 44.560 & 5.662 \\
\hline & & Other mfd. products & 21.810 & 0.451 \\
\hline & & Chemical products & 7.602 & 0.729 \\
\hline & & Minerals & 0.000 & 0.718 \\
\hline & & Metals & 3.259 & 1.169 \\
\hline \multirow{5}{*}{$\begin{array}{l}\text { Rest of } \\
\text { South East } \\
\text { Asia }\end{array}$} & \multirow{5}{*}{0.620} & Coal, oil, gas & 41.399 & 5.260 \\
\hline & & Apparel & 15.888 & 6.391 \\
\hline & & Textiles & 11.259 & 3.954 \\
\hline & & Other. mfd. products & 9.231 & 0.191 \\
\hline & & Services & 7.052 & 0.677 \\
\hline \multirow{5}{*}{ Senegal } & \multirow{5}{*}{0.479} & Services & 22.069 & 2.120 \\
\hline & & Chemical products & 21.118 & 2.025 \\
\hline & & Food products & 14.711 & 9.119 \\
\hline & & Other mfd. products & 12.240 & 0.253 \\
\hline & & Transport & 10.395 & 2.372 \\
\hline
\end{tabular}

3

$$
\text { II } S_{r}=\frac{1}{2} \cdot \sum_{i}\left|\frac{x_{r i}}{\sum x_{r i}}-\frac{m_{r i}}{\sum m_{r i}}\right|
$$

With this formula, we obtain the inter-industry specialization indicator that the higher it is, the more the trade balance is based on a small number of sectors, and conversely, the lower it is, it provides a better distribution of comparative advantages, and therefore a balance of export performance. 


\section{Methodology}

The MIRAGE (Modeling International Relationships in Applied General Equilibrium) model is a multi-sector, dynamic, multi-region computable general equilibrium (CGE) model devoted to trade policy analysis. The model is extensively described in Decreux and Valin (2007)and the implications of its features compared with other CGE models are analyzed in Bouët (2008).

Why choose a general equilibrium model? The partial equilibrium methodology has advantages in terms of being more transparent in its assumptions and easier for non-experts to understand. But both have a role and we incorporate both here, comparing the CGE results to those from Laborde (2008) using detailed data and a partial equilibrium approach.

The advantage of general over partial equilibrium models is that they take into account the economy-wide effects of trade liberalization, not just the sectoral changes induced by tariff changes. Specifically, when tariffs are lowered, the sector production contracts, decreasing demand for factors of production used extensively in that sector, as well as the remuneration of those factors. This, in turn, affects production in other sectors, which cannot be observed in the partial equilibrium framework. Trade liberalization also implies a decrease in tariff revenues for importing countries, which can involve contraction in services or public transfers. ${ }^{5}$ All these economic-wide effects need to be evaluated to appreciate the full impact of trade liberalization. In addition, the MIRAGE model incorporates recursive dynamics (Bouët 2008), which involves simulating the trade shock over a period of 10 years (considered as a benchmark) to reflect global economic changes resulting from changes to capital stocks or land supply due to changes in remuneration.

Here, simulations are run until 2020 to measure the long-term impact of the policy scenarios. The model is applied using data on the economic structure and trade of 113 countries in 57 sectors from the Global Trade Analysis Project (GTAP) database version 7 (Narayanan and Walmsley, 2008), and data on trade policies, including preferential tariff levels, from the MAcMapHS6 version 2database (Boumellassa, Laborde, and Mitaritonna, 2009). ${ }^{6}$

While these tools have been widely used in numerous assessments of global or regional trade agreements, specific modifications have been done for this study. First, the tariff data set has been updated so that the baseline reflects important trade policy changes since MAcMapHS6 was last updated in 2004 (see next section). Second, the trade matrix was adjusted to discriminate between "real" trade and virtual (or potential) trade. Our focus on LDCs requires particular care in the use of the data because of weaknesses and gaps in reporting by those countries and the problems are compounded in the case of potential exports that are blocked by prohibitive tariffs in importing countries.

\footnotetext{
${ }^{5}$ It is important to underline that in most cases the main resource for LDC governments is tariff revenues.

6 The MAcMapHS6 database has the most detailed information available on market access barriers and preferential trading arrangements, including bound and applied tariffs under World Trade Organization rules, and preferential tariffs arising from reciprocal regional trade agreements or unilateral preference programs, such as those studied here.
} 
To make the modeling and analysis tractable, the data have been aggregated into 36 countries or regions and 28 sectors, with a focus on LDCs and the products they export. The geographic and sectoral composition are shown in Annex Table 1. Our aggregation program is based on four criteria of selection to justify why some countries of interest are included in larger regions: the availability of the data, the reliability of the data, export and country specialization similarities, and consideration of existing preferential programs.

First, the geographic coverage is constrained in the sense that it depends on the availability of good quality, recent input-output tables. The GTAP database does not supply consistent information for all countries but presents data for regional aggregates ${ }^{7}$. The second issue is the reliability of existing data and some obvious inconsistencies can be identified that should be corrected.

For example, in the case of potential exports that are currently blocked by prohibitive tariffs, the trade matrix in the GTAP database allows for the possibility of trade creation by using constructed trade values instead of zeroes. To illustrate, the trade matrix of the GTAP database includes "virtual" merchandise trade flows related to travel expenditures: rather than treating them as an export of services, so that the expenses of a Japanese tourist in Cambodia are translated in the database as a dutiable export of the consumed goods from Cambodia to Japan. But these "virtual" trade flows can be problematic in our assessment when it creates non-negligible exports from a LDC to an OECD country after removal of a high tariff on a specific commodity. For instance, the GTAP database displays a virtual export of processed rice of about $\$ 100,000$ by Senegal to Japan to avoid a zero and allow for the possibility of exports if Japan's 340 percent tariff on rice were removed. Based on the model parameters (Armington elasticities for imperfect substitutes), however, the elimination of the duty can lead to a 15-fold increase in Senegalese exports of rice to Japan. Unfortunately, this flow is purely artificial and there is no way of knowing whether trade liberalization would boost Senegalese exports or by how much, given high transportation costs and other constraints. Due to the magnitude of the shock, this sort of problem could lead to significant bias in our results.

To address the problems created by constructed trade values, we split the GTAP trade matrix into two categories: real trade flows, based on the trade data inputs to the GTAP database by Mark Gehlhar, and virtual ones. ${ }^{8}$ Tariffs, and their elimination, will affect only the former category and since the liberalization is by more developed and advanced developing countries that have good data, this is not a problem for our analysis. In addition, we have checked the quality of the input-output tables for key products in the LDC countries we focus on to avoid important mistakes due to data quality problems. For instance, the GTAP7 database shows that 15 percent of the production cost of processed rice in Senegal is due to imported wheat and 0 percent to the local paddy rice. This mistake in the construction of the IO table will also lead to serious problems in the CGE assessment since it implies that Senegal can export rice without

\footnotetext{
${ }^{7}$ The list of GTAP aggregates is following: Rest of Oceania, Rest of East Asia, Rest of Southest Asia, Rest of South Asia, Rest of North America, Rest of South America, Rest of EFTA, Rest of Former Soviet countries, Rest of Europe, Rest of Western Asia, Rest of Western Africa, Rest of Central Africa, Rest of Eastern Africa, Rest of North Africa, Rest of South African Customs Unions. These regions include some of the least developed countries.

${ }^{8}$ See the description of the database at https://www.gtap.agecon.purdue.edu/databases/trade data.asp.
} 
producing it and simply by importing wheat. We fix such issues by reallocating the intermediate consumption to the appropriate sector in the 10 table.

Unfortunately, since the poorest countries have the least-available and lowest-quality data, many of the LDCs that we are interested in examining are either missing or have only partial data and can be included only on a weighted basis in larger regional aggregates. To illustrate, consider the aggregated region of "rest of Africa". This region is composed of heterogeneous states, including LDCs such as Benin, Guinea, Mali, Liberia, Sierra Leone, Burundi or Rwanda but also some vulnerable economies that are not eligible for DFQF programs, such as Cameroon, Kenya, Namibia or Swaziland. But, all these countries are already included in sub regional zones in the GTAP database. There are only two LDCs that could be isolated: Uganda and Tanzania but they suffer from severe unreliability of the data, since the latest IO tables date back to 1992. With those caveats, we tried to select for special analysis a range of LDCs from Africa (Ethiopia, Madagascar, Malawi, Senegal) and Asia (Bangladesh, Laos/Cambodia ${ }^{9}$ ) that produce a range of products, both clothing and agricultural products. Similar factors around regional and export diversity drove the decision on which other small and vulnerable economies, and which preference-giving countries to isolate in the analysis. For preference-giving countries, the aggregation program is clearly conducted by the similarity of trade policies and by the perspective given for any preferential agreement. For instance, Australia and New Zealand belong to the same free trade zone and apply the same preferential agreements. Furthermore, one of our main objective is to accentuate the role of emerging markets in helping the LDCs, thus Brazil, China, India, Korea, Mexico and Turkey are treated separately.

\section{The Baseline}

The first issue is to identify where we are now with respect to LDC market access. The Millennium Declaration approved by UN members in 2000 called for developed countries to provide DFQF market access for LDCs on essentially all products. The ministerial communiqué released by the WTO in Hong Kong in 2005 reaffirmed this commitment, but, at the insistence of U.S. negotiators, defined "essentially all products" as 97 percent of tariff lines. ${ }^{10}$

Most of Europe has already opened markets for 100 percent of exports from LDCs, as have Australia and New Zealand. ${ }^{11}$ Japan and Canada provide access for over 98 percent of products for LDCs, while the United States provides duty-free access for only around 80 percent of products for LDCs outside sub-Saharan Africa and Haiti, and South Korea's preference program for LDCs covered only 75 percent of tariff lines at the time the analysis was done. ${ }^{12}$ Among other OECD countries, Turkey provides DFQF access for most products outside agriculture and Mexico does not yet have a preference program. India and China also adopted preference

\footnotetext{
${ }^{9}$ Laos and Cambodia are two Asian LDCs with similar export profiles that have been grouped into one region because of data issues.

${ }^{10}$ See, for example, the analysis in Oxfam International (2005).

${ }^{11}$ We ignore the fact that the EU program excludes armaments as they are commercially insignificant.

12 In January 2010, South Korea raised the product coverage of its program to 85 percent tariff lines and announced that it will further raise the coverage to 95 percent by 2012 .
} 
programs for LDCs in recent years. These programs are described in more detail in Elliott (2009). Finally, at the WTO ministers' meeting in Geneva in December 2009, Brazil announced that it would introduce a program in 2010, rather than waiting for the conclusion of the Doha Round, as it had earlier insisted. ${ }^{13}$

Since the MAcMapHS6 version 2 database is based on 2004 data, we needed to update the database to reflect relevant trade policy changes occurring since then, including:

- expanded duty-free access for LDCs in

o Japan

o South Korea

o India

o China

o Switzerland

o Turkey

- the phasing out of the implementation period for the protocol products in the EU27 for the EBA (rice, sugar, bananas)

- implementation of free trade agreements between

0 the United States and Central America and the Dominican Republic (CAFTA-DR)

0 India and South Asian neighbors (SAFTA)

0 the Economic Partnership Agreements between the EU27 and ACP countries that have signed an agreement or at least an interim agreements.

\section{The Scenarios}

In order to explore a range of possible outcomes, we analyzed 4 different scenarios:
A. $97 \%$ of tariff lines liberalized by OECD countries for LDCs.
B. $100 \%$ DFQF given by OECD countries to LDCs.
C. $100 \%$ DFQF given by OECD countries to LDCs. and other designated countries (small and vulnerable economies - SVES -).
D. $100 \%$ DFQF given by OECD countries plus Brazil, China, and India to LDCs.

All scenarios are implemented in 2010.

In the first scenario, liberalization only applies to $97 \%$ of tariff lines and preference-giving countries are free to select the products excluded. In this case, we use the political economy criterion developed by Jean et al., (2010) to select the tariff lines excluded from liberalization. This approach is central to this study in the sense that it is more realistic to assume that givingcountries optimize their trade policies, taking into account politically-sensitive products ${ }^{14}$. It is

\footnotetext{
${ }^{13}$ See his statement at http://www.wto.org/english/thewto e/minist_e/min09 e/min09 statements e.htm.

${ }^{14}$ The initial model of Jean et al (2010) concerns only agricultural products. Actually, one important assumption of their modeling is that the share of agricultural dutiable imports in total expenditure of importers is small. In our context, some manufactured products are included in the list of potential sensitive products, but obviously this assumption is also respected: in implementing the simplified version of the Jean et al. (2010) criteria, we just assume that for each product imported from LDCs, the share in total expenditures is small to have the parameter
} 
based on a political economy approach where the government (common agent) gives protection to economic sectors (multi-principals) against financial transfers and maximizes a function which includes national welfare and these financial transfers. As a result of this model, the government is supposed to select lines which maximize a political economy indicator depending positively on the height of the tariff and the magnitude of imports ${ }^{15}$.

Here, it is important to point out that if the method of Jean et al (2010) is a rigorous approach, two conceptual limits have to be remembered.

First, governments maximize a welfare objective function without taking into account changes in foreign trade policies. Thus the Jean et al. (2010) approach considers that each country makes its choices independently from the rest of the world. This can be interpreted as each country being small and a price taker on its imports.

Second, in the model of Jean et al. (2010) the prediction is that a single tariff applies to each product from all trade partners. But in reality, the pre-DFQF regime embodies a host of bilateral and regional trade agreements that stipulate different levels of bilateral tariffs. The interpretation of the Jean et al. (2010) model used here is adjusted to accommodate this dimension. In the present approach, we consider that each pair product-exporter is a differentiated product in the CES function.

With the Mirage model simulations, it is possible to underline some interesting results that would be generated by these different scenarios, and in particular the distribution of potential gains and losses in terms of exports, production variation and social welfare. Welfare variation in this model is estimated on the basis of the Hicksian concepts of equivalent variation ${ }^{16}$. In addition to the impact on different groups of preference beneficiaries, we are also interested in the impact on production in the preference-giving countries. The remaining tariff peaks in developed countries are the result of lobbying by powerful political constituencies, so, in order to assess the political feasibility of various scenarios, it is important to analyze the impact in those countries as well.

Before exploring and analyzing the results, it is important to emphasize the implications of using Armington elasticities, which assume that imported and domestic products are heterogeneous and, therefore, that substitution between them is more limited than with homogeneous products. That, in turn, means that the predicted values of the trade changes (in response to prices variation) are smaller than those implied by models with homogeneous

\footnotetext{
"1-s" in Jean et al. (2010) article close to 1, the import demand elasticity becoming the same for all goods under the CES assumption.

${ }^{15}$ It is noteworthy that the pre-DFQF protection structure needs to be a political optimum in order to calibrate the model and choosing sensitive products is done in a way that minimizes political welfare losses. We model here a process under which governments maximize their objective function under the constraint that DFQF is given to some partners with only $3 \%$ of tariff lines still taxed. Consequently the post-DFQF equilibrium is suboptimal compared to the initial case, but it is a new optimum under this new constraint.

${ }^{16}$ The Hicksian equivalent variation is defined as the monetary amount that would need to be given to the representative agent in order to reach the same level of welfare in the free trade case as under initial prices.
} 
products. Moreover the levels of these elasticities are equal to those used by the GTAP model, but are less than those used by the LINKAGE model at the World Bank. Thus, the Mirage model is quite conservative.

\section{The Impact of 100 percent Market Access in OECD Countries for LDCs}

Previous studies by Berisha-Krasniqi, Bouët, Laborde and Mevel (2008), among others, demonstrated that tariff peaks in rich countries are concentrated in a few tariff lines and, therefore, 97 percent duty-free access provides very little benefit. ${ }^{17}$ That result was confirmed by this analysis, which shows no LDC gaining even as much as one-tenth of one percent in additional exports from 97 percent product coverage. For similar reasons, including that LDC exports are relatively concentrated, 97 percent coverage by more advanced developing countries also results in relatively small export gains. For that reason, in the discussion that follows, we focus on the scenarios involving 100 percent DFQF market access. The results in terms of overall export changes for all scenarios are presented in Annex Table 3.

In this section, we will focus on the results when OECD countries provide 100 percent DFQF market access, and we examine the effects both for those benefiting from DFQF market access and others that might suffer preference erosion. ${ }^{18}$ Table 1 shows the change in exports and overall welfare for one Asian and four African LDCs, as well as two aggregates containing LDCs-Rest of Southeast Asia, which includes Cambodia and Laos (as well as oil exporter Brunei), and Rest of Africa, which contains a mix of LDCs, as well as other low- and middleincome countries, making it particularly difficult to interpret.

Table 1: World Average protection rates on LDCs exports, before and after DFQF

\begin{tabular}{|l|r|r|r|}
\hline & $\begin{array}{l}\text { Initial Average } \\
\text { protection on LDC } \\
\text { exports }\end{array}$ & $\begin{array}{l}\text { Average protection on } \\
\text { LDC exports after } \\
\text { 100\% DFQF }\end{array}$ & Variation (\%) \\
\hline Bangladesh & $5.5 \%$ & $3.3 \%$ & -39.848 \\
Ethiopia & $9.7 \%$ & $9.7 \%$ & -0.009 \\
Madagascar & $1.7 \%$ & $1.7 \%$ & -0.326 \\
Malawi & $18.3 \%$ & $6.3 \%$ & -65.508 \\
Mozambique & $4.8 \%$ & $4.8 \%$ & -0.010 \\
Rest of Africa & $5.4 \%$ & $5.1 \%$ & -3.976 \\
Rest of South East Asia & $1.9 \%$ & $1.2 \%$ & -34.788 \\
Senegal & $5.8 \%$ & $5.8 \%$ & -0.01 \\
\hline
\end{tabular}

\footnotetext{
${ }^{17}$ See, for example, Hoeckman B, Ng F and Olarreaga M, 2002, Eliminating Excessive Tariffs on exports of Least Developed Countries

${ }^{18}$ Annex Table 3 shows the results for additional economy-wide variables for all countries and regions in the database for the two central scenarios: where only the OECD provides 100 percent DFQF market access for LDCs, and where Brazil, China, and India do so as well.
} 
These figures illustrate how DFQF can generate relatively large reductions in average tariff for some LDCs. Average tariffs are weighted by the share of each sector in the national production (and not exports to avoid bias due to tariffs) and that means that countries that are most dependent on one or two sectors where they have a strong comparative advantage and face relatively high tariffs will experience sharper declines in the average protection rate that they face and that will allow them to boost their exports relatively more (Bangladesh, Malawi). Conversely, when the countries are relatively more diversified, or they concentrated in sectors with relatively low tariffs, such as some minerals, the impact will be less. For instance, if Mozambique should not expect a large decrease in the average tariff because more than half its exports are metals, which face low tariffs already. The same can be said for Senegal, which is specialized in manufactured goods (chemical or food products) that generally face low tariffs. Conversely, Malawi is strongly specialized in non-manufactured tobacco (other crops), imports of which are highly taxed by the United States. It is important to underline that if emerging markets are included in the analysis, the case of Senegal, for instance, will be improved by the removal of Indian tariffs on chemical products that will boost Senegalese exports.

Table2: Percentage change in Key Variables in 2020 from OECD implantation of 100\% DFQF for LDCs (sorted by change in welfare).

\begin{tabular}{|l|r|r|}
\hline DFQF Recipients & \multicolumn{1}{|l|}{ Exports } & Welfare \\
\hline Malawi & 12.97 & 2.65 \\
Rest of South East Asia & 2.52 & 0.95 \\
Ethiopia & 1.35 & 0.29 \\
Bangladesh & 4.16 & 0.29 \\
Mozambique & 0.39 & 0.17 \\
Senegal & 1.16 & 0.15 \\
Rest of Africa & 0.08 & 0.03 \\
Madagascar & -0.03 & -0.02 \\
\hline
\end{tabular}

\begin{tabular}{|l|r|r|}
\hline Otherdeveloping countries & \multicolumn{1}{|c|}{ Exports } & Welfare \\
\hline Mauritius & 0.03 & 0.02 \\
Central America & 0.14 & 0.01 \\
South Africa & 0.02 & 0.00 \\
Rest of Asia and Oceania & 0.00 & 0.00 \\
Middle East and North Africa & 0.01 & 0.00 \\
Nigeria & 0.01 & 0.00 \\
Rest of Eastern Europe & 0.00 & 0.00 \\
Sri Lanka & -0.01 & 0.00 \\
China & -0.03 & 0.00 \\
India & -0.01 & 0.00 \\
Pakistan & -0.04 & 0.00 \\
Philippines & -0.01 & 0.00 \\
Vietnam & -0.01 & -0.01 \\
Brazil & -0.03 & -0.01 \\
Bolivia & -0.03 & -0.01 \\
Indonesia & -0.03 & -0.01 \\
Rest of Latin America & -0.05 & -0.01 \\
Paraguay & -0.04 & -0.03 \\
\hline
\end{tabular}

Turning to changes in exports and welfare, the model suggests that Madagascar might suffer very small losses, but all other LDCs for which we have data show gains from 100 percent DFQF access in OECD markets. It is also notable, given the concerns about the extension of U.S. 
preferences to Asian apparel exporters that the export losses in Madagascar in this scenario come in agriculture, not the apparel sector. Additional details on the potential implications of these changes for sub-Saharan African LDCs are discussed in Box 2 at the end of this section. Moreover, these small losses are reversed if the major emerging markets also provide dutyfree, quota-free market access (see discussion below and Annex Table 4).

Overall, Malawi is the biggest gainer by far because of an unusual set of circumstances-a relatively high dependence on tobacco exports facing an unusually high, 350 percent, tariff in the U.S. market, which leads to a sharp increase in exports of that product. Thus, this case also underscores the need for complementary government policies to guard against increased export concentration and commodity dependence when trade barriers are lifted.

The reported gains for the rest of Africa region are noticeably smaller than for the individual African LDCs and this could be due to the fact that only a subset of countries in the aggregation are LDCs that receive expanded access. As expected, an examination of more detailed results for Southeast Asia shows that the gains are mostly due to increased exports of apparel to the U.S. market, as are the gains for Bangladesh. The sectoral change in exports, by country or region, for this scenario is shown in Annex Table 5. The increased export of apparel from Southeast Asia probably represents mostly exports from Cambodia, since Laos is small and has very little export capacity and Brunei, the third country in that aggregate, exports mostly oil and faces low tariffs.

What is also notable in Table 2 is that other competing countries that might be expected to suffer from preference erosion-Mauritius, South Africa, and Central America-instead show gains, albeit very small. And for other developing countries, if they suffer losses at all, estimated losses fall well below one-tenth of one percent of total exports or national income.

To put the potential gains in some perspective, we can compare them to two other sets of results-general equilibrium estimates of the welfare gains from global free trade, and partial equilibrium estimates of the export gains of moving from 97 percent to 100 percent product coverage in the context of a feasible Doha Round outcome (based on what was on the table in the summer of 2008 when the talks collapsed).

With respect to the gains from global free trade, Bouët (2008) uses the same MIRAGE model and estimates that global free trade would produce average welfare gains of around $0.8 \%$ of national income for low-income countries. In contrast to unilateral trade preferences in OECD markets, global free trade would bring additional gains from access to other developing-country markets, as well as from these countries' liberalization of their own markets. Thus, it is notable that the estimated benefits from 100 percent market access for LDCs show welfare gains well above the level estimated for global free trade for Malawi and Southeast Asia, and of more than a third of that level for Bangladesh and Ethiopia.

While they are the only technique for showing the global distribution of gains and losses from changes in trade policy, computable general equilibrium models have features that make the size of the estimates quite conservative. To suggest the range of possible benefits, Table 3 contrasts the CGE results for LDCs with estimates from Laborde (2008), which uses a less 
conservative, partial equilibrium, approach that takes into account only potential changes in demand in the liberalizing countries, and not potential supply constraints in the exporting countries. ${ }^{19}$ In addition to using a different estimation method, the Laborde results are in the context of the WTO's Doha Round and thus cover only the 32 WTO members.

The partial equilibrium analysis suggests that total LDC exports could increase as much as \$2 billion, or 17 percent. The largest relative gains in both sets of estimates go to Malawi, as well as the Asian LDCs that face tariff peaks on their exports of apparel to the U.S. market. Other African LDCs see smaller gains, but that is not surprising since they generally have good access in their major markets. The partial equilibrium estimates of gross gains are also available for other LDCs that are members of the WTO and those show large gains for Benin and Sierra Leone, and gains of a quarter or more, relative to base-year exports, for Maldives, Nepal, and Niger (Laborde 2008, p. 22).

Table 3: Percentage Variation in Exports for two scenarios in two models

\begin{tabular}{|c|c|c|c|c|}
\hline & \multicolumn{2}{|c|}{$100 \%$ OECD DFQF } & \multicolumn{2}{|c|}{$100 \%$ OECD + MICS ${ }^{b}$} \\
\hline & General Equilibrium & Partial Equilibium ${ }^{a}$ & General Equilibrium & Partial Equilibium \\
\hline Bangladesh & 4.16 & 28.96 & 4.82 & 38.55 \\
\hline Cambodia $^{c}$ & 2.52 & 31.27 & 2.55 & 32.96 \\
\hline Clothing & 19.49 & n.a. & 19.51 & n.a. \\
\hline Ethiopia & 1.35 & n.a. & 2.24 & n.a. \\
\hline Madagascar & -0.03 & -0.74 & 0.57 & 20.61 \\
\hline Malawi & 12.97 & 215.08 & 13.91 & 240.41 \\
\hline Mozambique & 0.39 & 16.29 & 1.41 & 128.11 \\
\hline Senegal & 1.16 & 8.46 & 9.38 & 64.83 \\
\hline All WTO LDCs ${ }^{d}(\%)$ & n.a. & 16.97 & n.a. & 44.36 \\
\hline All WTO LDCs ${ }^{\mathrm{b}}(\mathrm{mil}$ & n dollars) & 2108 & & 7731 \\
\hline
\end{tabular}

n.a. = not available.

a. Canada, Japan, Norway, Switzerland, United States; the EU is excluded because it provides 100 percent DFQF.

b. The CGE model includes South Korea and Mexico in OECD, while the partial equilibrium includes them with Brazil, China, and India as middle-income countries.

c. In the CGE model, the results are for the regional aggregate, "rest of South East Asia," which includes Laos and Brunei, as well as Cambodia, which dominates exports.

d. The partial equilibrium estimates are in the context of a Doha Round agreement and thus only include WTO LDCs.

Finally, it should be noted that neither the general nor the partial equilibrium estimates account for rules of origin or other administrative obstacles that can block access, even when traditional trade barriers are eliminated. Thus, the benefits are likely underestimated because they assume full access in the EU market, despite restrictive rules of origin in the EBA program

\footnotetext{
${ }^{19}$ In this model, LDCs have no supply constraints and react perfectly to the increased demand for their products when barriers are removed. See Fontagne, Laborde, and Mitaritonna (2008) for details.
} 
that are known to inhibit exports. ${ }^{20}$ But the benefits of moving to 100 percent DFQF access in other markets would also be less than estimated here if programs for LDCs create or retain similar obstacles. That underscores the importance of including changes to restrictive rules of origin, as recommended by the CGD Working Group on Global Trade Preference Reform. ${ }^{21}$

\section{Box 2 The Impact on Africa of 100 percent DFQF Market Access in the United States}

Currently, Asian LDCs are outside of the more generous regional preference programs offered by the United States and because the GSP program that is available to them excludes apparel, they are among the biggest potential gainers from the adoption of 100 percent DFQF access in the U.S. market. But the potential increase in competition raises concerns among existing preference beneficiaries, especially in sub-Saharan Africa, where a handful of countries have been able to take advantage of AGOA to increase apparel exports. Unfortunately, our ability to explore these issues in the detail we would like is inhibited by lack of data: of the five major African apparel exporters (accounting for 90 percent of exports under AGOA), we have disaggregated data for only one LDC, Madagascar, as well as for Mauritius. Kenya, Lesotho, and Swaziland are included in the Rest of Africa aggregate.

The results that we have do not suggest that African apparel exporters will systematically lose out. More disaggregated results do show modest reductions in African apparel exports to the United States, generally in a range of one to one and a half percent of current exports. But if U.S. reform is embedded in broader global reform, as modeled here, sub-Saharan African exporters gain access in other markets as trade flows adjust globally.

As noted above, Madagascar is the only significant African LDC apparel exporter for which there is data and, while Madagascar is also the only country that does not gain from 100 percent DFQF market access in OECD countries, that result is not due to preference erosion in apparel. As shown in annex table 4, there is essentially no change in Madagascar's exports of apparel under this scenario. As also shown in that table, Mozambique, which is not currently a major exporter of apparel, would see a small gain, as would South Africa, a non-LDC. Mauritius, a major exporter and non-LDC, would see a very small loss, while Ethiopia, Malawi, and Senegal, which export very little apparel, would shift resources from that sector to others. It is also important to note, however, that rules of origin are not addressed here and the recently announced changes to those rules in the European Union are important in allowing adjustment to occur in that market as well.

Moreover, 100 percent product coverage is of benefit to Africa generally because benefits are currently narrowly concentrated in a few countries and products, mainly oil, and full coverage would eliminate the exclusions on agricultural exports. ${ }^{1}$ To the degree that there are losses from expanding preferences for all LDCs, it would be preferable to address these through targeted measures to increase competitiveness or to compensate the adjustment, rather than discriminating among LDCs.

\footnotetext{
${ }^{20}$ Additional benefits might now be realized as a result of the EU's announcement of new, less restrictive rules of origin under the EBA program, especially with respect to fish and apparel.

21 Information on the working group, as well as the final report, may be found at http://www.cgdev.org/section/initiatives/ active/reformingtradepreferences/global trade preference reform.
} 


\section{What Happens if the OECD Extends 100 Percent Access to Other Small, Poor Countries?}

We tested a different scenario for extending eligibility for DFQF market access in OECD countries beyond LDCs, where other small and vulnerable economies (SVEs) are included in the preferential program. More precisely, the additional small and vulnerable countries that fall below the World Bank's low middle-income (per capita) threshold with total national incomes below $\$ 50$ billion, which excludes Pakistan and Vietnam because they are large, become DFQF recipients.

In addition, to test the sensitivity of the results to the country classification chosen, we implemented a fifth scenario that extends DFQF to all low-income-Countries (including VietNam and Pakistan in spite of their relatively large size). This scenario may also be of interest because both the EU and United States are considering extending some additional market access to Pakistan in the wake of last summer's floods.

Table 4 shows the estimated change in exports for potential beneficiaries, as well as those left out, under each scenario and compares them to the LDC-only scenario. In general, extending DFQF market access to other low-income countries, even when Pakistan and Vietnam are included, entails generally small losses for both LDC beneficiaries and excluded countries, and, when they are included, large gains for Pakistan and Vietnam. There are losses for Sri Lanka, the Philippines, and Central America, but they remain well under one-half of one percent in those cases. Unfortunately, the benefits for the smaller low-income countries are harder to assess because of data limitations, with only Pakistan and Vietnam having sufficient information available to assess the impact in detail. The increase in exports for the rest of Africa region could be due to increased benefits for low-income countries in that region.

Extending DFQF market access to other small and low middle-income countries creates large export gains for those countries for which we have data, especially Paraguay (17\%) and Sri Lanka (21\%). The African, Central American, and Latin American residual regional aggregates also gain, presumably because they include small, low middle-income countries that would gain from additional access. But this scenario leads to modest reductions in the gains for Asian LDCs and either larger declines in gains or outright losses for African LDCs, including of more than 1 percent of exports for Ethiopia and Madagascar. The inclusion of low income countries, especially from Latin America and Asia, will expand the scope of products on which African LDCs will face increased competition, particularly in agriculture. Preference erosion losses also increase for other developing countries, though they are relatively small except for Mauritius. 
Table 4: Percentage Change in Export Volume in 2020 in Scenarios Where OECD Grants 100\% DFQF

\begin{tabular}{|c|c|c|c|}
\hline Region & B_ LDCsonly & C_OtherSVEs & All LICs ${ }^{(1)}$ \\
\hline \multicolumn{4}{|l|}{ LDCs } \\
\hline Bangladesh & 4.16 & 3.46 & 3.38 \\
\hline Ethiopia & 1.35 & -0.49 & 0.90 \\
\hline Madagascar & -0.03 & -2.28 & -0.70 \\
\hline Malawi & 12.97 & 4.71 & 11.15 \\
\hline Mozambique & 0.39 & -0.48 & 0.21 \\
\hline Senegal & 1.16 & 0.80 & 1.12 \\
\hline Rest of South East Asia & 2.52 & 2.40 & 2.25 \\
\hline Rest of Africa & 0.08 & 0.49 & 0.29 \\
\hline \multicolumn{4}{|l|}{ Low-income countries } \\
\hline Pakistan & -0.04 & -0.05 & 11.90 \\
\hline Vietnam & -0.01 & -0.06 & 18.00 \\
\hline \multicolumn{4}{|l|}{ AdditionalSVEs } \\
\hline Bolivia & -0.03 & 3.46 & -0.02 \\
\hline Paraguay & -0.04 & 16.95 & -0.03 \\
\hline Sri Lanka & -0.01 & 20.94 & -0.27 \\
\hline \multicolumn{4}{|l|}{ Otherdeveloping countries } \\
\hline Brazil & -0.03 & -0.12 & -0.07 \\
\hline China & -0.03 & -0.06 & -0.10 \\
\hline India & -0.01 & -0.04 & 0.04 \\
\hline Indonesia & -0.03 & -0.07 & 0.02 \\
\hline Mauritius & 0.03 & -1.96 & -0.35 \\
\hline Nigeria & 0.01 & 0.03 & 0.03 \\
\hline Philippines & -0.01 & -0.07 & -0.17 \\
\hline South Africa & 0.02 & -0.02 & 0.04 \\
\hline Central America & 0.14 & 0.83 & -0.02 \\
\hline Middle East and North & & & \\
\hline Africa & 0.01 & 3.51 & 0.00 \\
\hline Rest of Asia and Oceania & 0.00 & 0.00 & 0.08 \\
\hline Rest of Eastern Europe & 0.00 & 0.12 & 0.10 \\
\hline Rest of Latin America & -0.05 & 0.78 & -0.07 \\
\hline
\end{tabular}

(1) additional scenario included all the LICS 


\section{How Important is Improved Access in Large, Emerging Markets?}

For some countries, particularly in Africa, extension of full market access by large emerging markets would significantly expand the potential gains from unilateral preference programs. In these scenarios, we include as emerging markets China and India, which have implemented partial duty-free preferences for LDCs, and Brazil, which also recently announced that it will introduce a program soon. ${ }^{22}$ China announced a few years ago that it would provide duty-free, quota-free access on 440 tariff lines for 30 sub-Saharan African with which it has diplomatic relations and then announced an expansion of that in late 2009 to 95 percent of tariff lines. It also offers DFQF on a smaller number of tariff lines to Asian LDCs with whom it has relations. India's programs provide DFQF market access on 85 percent of tariff lines and partial duty reductions on another 9 percent, phased in over several years. The announcement by Foreign Minister Celso Amorimin Geneva last year said that Brazil would begin providing duty-free access for LDCs on 80 percent of items by the end of 2010 and then increase coverage to "all tariff lines" over four years. ${ }^{23}$

Unfortunately, we do not have full information on these programs and we have to make some assumptions to identify the products likely to be excluded in the partial product coverage scenario, which could skew the results somewhat. From what we do know about these programs, the political economy and the range of import-sensitive products appear to be similar to what we find in OECD countries. Thus, China's original list of covered products excluded cotton, sugar, most fruits and vegetables, and a number of textile and apparel products. India includes sugar and cotton, but excludes a number of other agricultural products and offers no or only partial preferences on many textile and apparel products. Textiles and apparel were also raised as sensitive by industry groups in Brazil. ${ }^{24}$

The analysis suggests that meaningful impact on LDC exports and welfare (Table 5 and Annex Table 4) will result only if emerging markets also provide 100 percent product coverage.

\footnotetext{
${ }^{22}$ Turkey is included as a member of the OECD in those simulations.

${ }^{23}$ Because Minister Amorim's statement also refers to the Hong Kong communiqué, it is not entirely clear whether the commitment is to eventually cover 100 percent or 97 percent of tariff lines. See his statement on the WTO website at http://www.wto.org/english/thewto e/minist e/min09 e/min09 statements e.htm.

${ }^{24}$ On China, see Minson (2007); for a comparison of China and India, drawing on the political economy literature, see Engel (processed); and on Brazil, see Bridges Weekly Trade News Digest, Vol. 10, Number 41, December 6,2006.
} 
Table 5: Comparing the Percentage Change in Export Volume in 2020 when Brazil, China, and India also grant $100 \%$ DFQF to LDCs

\begin{tabular}{|c|c|c|c|c|c|}
\hline LDCs & OECD only & OECD + EMs & EMs & OECD only & OECD + EMs \\
\hline Malawi & 12.97 & 13.91 & Brazil & -0.03 & 0.00 \\
\hline Senegal & 1.16 & 9.38 & China & -0.03 & -0.02 \\
\hline Bangladesh & 4.16 & 4.82 & India & -0.01 & 0.64 \\
\hline Rest of South East Asia & 2.52 & 2.55 & & & \\
\hline Ethiopia & 1.35 & 2.24 & & & \\
\hline Mozambique & 0.39 & 1.41 & & & \\
\hline Madagascar & -0.03 & 0.57 & & & \\
\hline Rest of Africa & 0.08 & 0.22 & & & \\
\hline
\end{tabular}

\begin{tabular}{|l|r|r|}
\hline Otherdeveloping countries & OECD only & OECD + EMs \\
\hline Bolivia & -0.03 & -0.04 \\
Central America & 0.14 & 0.14 \\
Indonesia & -0.03 & -0.03 \\
Mauritius & 0.03 & 0.05 \\
Middle East and North Africa & 0.01 & 0.00 \\
Nigeria & 0.01 & -0.13 \\
Pakistan & -0.04 & -0.06 \\
Paraguay & -0.04 & -0.03 \\
Philippines & -0.01 & -0.02 \\
Rest of Asia and Oceania & 0.00 & 0.01 \\
Rest of Eastern Europe & 0.00 & 0.01 \\
Rest of Latin America & -0.05 & -0.04 \\
South Africa & 0.02 & 0.03 \\
Sri Lanka & -0.01 & -0.05 \\
Vietnam & -0.01 & -0.01 \\
\hline
\end{tabular}

Focusing on the 100 percent product coverage scenario where emerging markets join OECD countries, this is the only scenario examined where Madagascar shifts from small losses to small gains. This scenario also results in more marked increased gains for several other LDCs in Africa, particularly Ethiopia, Mozambique, and Senegal, with more modest additional benefits for the Asian LDCs. The African regional aggregate also sees a large relative gain, though it remains small in absolute terms.

The partial equilibrium estimates in Table 2 show a similar distribution of gains, but of a much larger magnitude. In this scenario, exports from Madagascar, Mozambique, and Senegal could increase by as much as 21 percent, 128 percent, 65 percent, respectively, compared to increases of 10 percent or less in the general equilibrium modeling. Overall, the partial equilibrium estimates for all WTO LDCs suggest an average increase in exports of up to 44 percent, worth an additional $\$ 8$ billion for these countries. 
Perhaps the most interesting result in the general equilibrium analysis is that all three emerging markets granting 100 percent DFQF market access improve their position relative to the scenario where only the OECD grants DFQF market access to LDCs. Other developing countries see little or no preference erosion as a result of the expanded access for LDCs (Table 4).

\section{What is the Impact of 100 percent DFQF Market Access for OECD Countries?}

The overall conclusion regarding the impact on preference-giving countries-both developed and developing-is that it is small. Annex Table 3 shows the results from the CGE model for changes in exports, GDP, and welfare, among other indicators, and they are indistinguishable from zero for all preference-giving countries when 100 percent DFQF for LDCs is given, either by the OECD only, or OECD plus Brazil, China, and India. Table 5 shows the sector-specific variation in production for preference-giving countries and, while the impact often exceeds the average, economy-wide impact (not surprisingly),there is only a handful of cases where production declines rise to even as much as 0.5 percent.

For the OECD countries not already granting 100 percent product coverage, the most sensitive products are often agricultural products subject to tariff-rate quotas to help control supply and prop up prices. The expressed concern, whether in Japan for rice and dairy, Canada for dairy and poultry, or sugar in the United States, is that expanded market access for LDCs will destabilize the price support programs. It is true, that the estimated reductions for agricultural products that are commonly controlled through quantitative restrictions could be suppressed because the model cannot completely address the prospects for trade creation in cases where little or no trade currently exists. Still, one would not expect large gains for potential LDC exporters of commodities such as meat and dairy products because it would be difficult for poor countries to meet rich-country food safety standards for these products. And in other sectors, the prospects for significant supply expansion are limited.

To explore one example in more detail, are the CGE results in Table 6 and Annex Table 5, which show very little change in either exports or U.S. production of sugar from providing 100 percent DFQF for LDCs, plausible? While the estimate of no change in production is influenced by the restrictions imposed on trade creation in cases of zero trade, a brief survey of LDC exporters and markets also suggests there is little reason to expect a large surge in U.S. imports if sugar is included in DFQF for LDCs. Currently, only two African LDCs-Malawi and Mozambique-have access to the U.S. market under the historical quota allocation system and their quotas are small. Only two other African LDCs-Ethiopia and Zambia-have had exportable sugar surpluses in recent years. But African sugar producers tend to be relatively high-cost and transportation costs are also high. ${ }^{25}$ The European Union is also the traditional market for African exporters, though some of those exports could shift to the American market since the reform of the EU sugar regime (forced by a WTO complaint by Brazil) reduced the internal price from 50 percent higher to roughly the same level as in the United States.

\footnotetext{
${ }^{25}$ The exception to this is Sudan, which is planning large investments in sugar production with the aim of boosting output ten-fold. But Sudan is currently excluded from U.S. preference programs and the U.S. market by comprehensive foreign policy sanctions over human rights and democracy issues.
} 
Table 6: Percentage Change in Production Volume from implementing $100 \%$ DFQF for LDCs*

\begin{tabular}{|l|rrrrrrrrrrr|}
\hline Sector & ANZ & Canada & EFTA & EU & Japan & Mexico & Turkey & \multicolumn{2}{c|}{ US } & Brazil & China \\
Fish & $-0,01$ & $-0,01$ & 0,00 & 0,00 & $-0,01$ & 0,00 & $-0,00$ & 0,00 & 0,00 & $-0,01$ & $-0,10$ \\
Leatherproducts & 0,02 & $-0,01$ & 0,02 & 0,00 & 0,02 & 0,01 & 0,09 & 0,05 & $-0,08$ & $-0,01$ & 0,47 \\
Milk & $-0,05$ & $-0,03$ & $-0,01$ & $-0,01$ & $-0,01$ & 0,01 & 0,02 & $-0,10$ & $-0,00$ & 0,01 & $-0,00$ \\
Oilseeds & $-0,97$ & $-0,57$ & 0,48 & $-0,17$ & $-0,38$ & $-0,45$ & $-1,56$ & $-0,99$ & $-0,41$ & $-0,33$ & $-0,07$ \\
Othercereal grains & 0,04 & $-0,06$ & $-0,01$ & $-0,00$ & $-0,01$ & 0,01 & $-0,12$ & 0,04 & 0,17 & 0,01 & 0,05 \\
Othercrops & 0,02 & $-0,40$ & 0,14 & 0,03 & $-0,03$ & $-0,14$ & $-0,66$ & $-0,76$ & $-0,05$ & $-0,03$ & $-0,14$ \\
Rice & 0,03 & 0,09 & 0,29 & 0,13 & $-0,00$ & $-0,00$ & $-0,32$ & 0,04 & 0,00 & 0,00 & 0,10 \\
Sugar & $-0,15$ & 0,01 & $-0,54$ & 0,21 & $-0,35$ & 0,01 & 0,06 & 0,01 & 0,15 & $-0,17$ & 0,03 \\
Textile & $-0,27$ & $-0,57$ & 0,05 & 0,07 & $-0,03$ & $-0,22$ & 0,08 & $-0,45$ & $-0,09$ & $-0,11$ & 0,21 \\
Vegetable and fruit & 0,04 & 0,05 & $-0,00$ & 0,00 & 0,01 & 0,00 & 0,06 & 0,03 & 0,01 & 0,00 & $-0,62$ \\
Vegetableoils and fats & $-0,51$ & $-0,91$ & $-1,36$ & $-0,24$ & $-0,27$ & $-0,07$ & 0,03 & 0,02 & $-0,50$ & $-0,46$ & $-0,20$ \\
Wearingapparel & $-0,10$ & $-0,01$ & 0,02 & 0,03 & $-0,00$ & $-0,03$ & 0,03 & $-0,13$ & $-0,06$ & $-0,21$ & 0,41 \\
\hline
\end{tabular}

*For OECD countries, when only they implement; for emerging markets, when they implement along with OECD. 
To explore further the potential for market disruption from increased African sugar exports, we applied a simple partial equilibrium analysis to this sector. Table 7 shows the impact on domestic production and prices from two scenarios, one where U.S. imports of sugar increase by 100,000 short tons, which would have almost no impact on U.S. prices and production, and a second with increased imports of 300,000 short tons, which would reduce production by 6 percent and average prices by 10 percent, to 20 cents per pound. ${ }^{26}$ Though there is no economic justification for the U.S. price-support program for sugar, these estimates suggest that at least some expansion of access is possible, without major disruption of the market, as long as that remains the political goal of the minority that controls policy.

Another sensitive sector for the United States is apparel and, here, both the CGE and partial equilibrium (Table 2 and Annex Table 5) results do show relatively large increases in apparel exports by Bangladesh and Southeast Asia (mostly by Cambodia). But, again, the impact on U.S. production is small, -0.45 percent for textiles and -0.13 for clothing. If removal of tariffs led to increased imports that are two to three times higher than estimated in the CGE model, closer to what is suggested by the partial equilibrium model (Table 1), and if the impact on production is proportional, it would still be in a range of one to two percent. ${ }^{27}$

There are two major reasons for the relatively limited impact on U.S. production. First, the increase in imports from the Asian LDCs is offset to some extent by small decreases in exports spread among a large number of other exporters. Secondly, LDCs tend not to compete in the same product lines as American producers, who are generally far more technology sophisticated and capital-intensive. This is illustrated by the fact that Bangladesh's apparel exports are equal to 12.4 percent of the volume of U.S. production, but only $2.75 \%$ of the value.

\footnotetext{
${ }^{26}$ The estimates were done using the partial equilibrium model in Hufbauer and Elliott (1994).

${ }^{27}$ The estimated 4 percent increase in Bangladeshi exports from the CGE model, shown in Table 1 is for all exports to all countries. As shown in Annex Table 4, the increase in exports of textiles and clothing, most of which would be to the United States, is nearly 13 percent. The partial equilibrium estimates of increased exports are a bit more than twice that figure for Bangladesh and roughly 50 percent higher for Cambodia.
} 
Table 7: Effects of enlarging the U.S. Sugar Quota

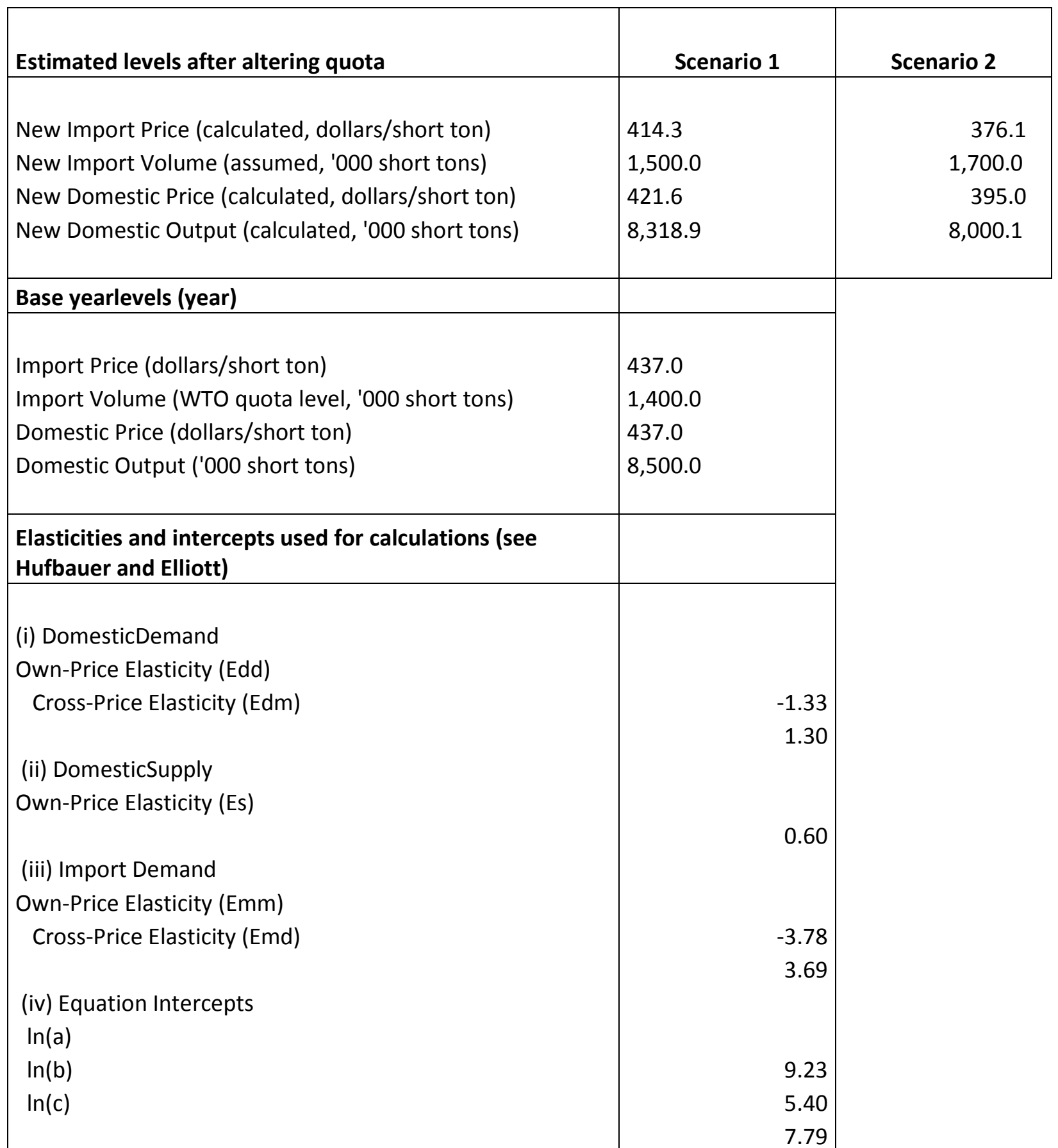

Source for model and parameters: Gary Clyde Hufbauer and Kimberly Ann Elliott, Measuring the Costs of Protection in the United States, Washington: Institute for International Economics, 1994, p. 81

Source for data: U.S. Department of Agriculture, U.S. Sugar and Sweeteners:

Recommended Data, online at http://www.ers.usda.gov/briefing/sugar/data.htm. 


\section{Conclusions}

Unilateral trade preference programs were created four decades ago to stimulate exports and help developing countries diversify their economies as part of their development strategies. Through preferences, but also regional and multilateral negotiations, many developing countries succeeded spectacularly in using trade as a tool of development, but the least developed countries lagged for a variety of reasons. The duty-free, quota-free market access initiative was developed to give these countries a boost.

While significant progress has been made toward the goal of improved market access for LDCs since the Millennium Declaration embraced it in 2000, much also remains to be done. This analysis helps to identify the distribution of potential costs and benefits from further progress. Several key conclusions that should inform policies in $\mathrm{G} 20$ countries stand out:

- There are still significant benefits for LDCs from removing the remaining barriers they face in OECD countries, but only if all products are covered. Since both rich-country tariff peaks and LDC exports are relatively concentrated, excluding as few as three percent of tariff lines, as proposed by the United States at the WTO ministerial meeting in Hong Kong in 2005, reduces the benefits to basically zero.

- Although it has nearly full access in its main markets, including in the United States under AGOA, sub-Saharan Africa can still gain from 100 percent DFQF market access that eliminates remaining agricultural restrictions in the U.S. markets.

- The gains for LDCs, especially in Africa, are significantly enhanced if Brazil, China, and India also provide 100 percent DFQF market access.

- There is little evidence of significant losses for other competing developing countries that are not LDCs, including Pakistan or Sri Lanka, nor is there evidence of net losses for Africa from the United States extending DFQF market access to Asian LDCs.

- The LDCs account for a trivial share of global exports, the reason for the initiative, and preference-giving countries thus have little to fear from extending full market access to them. The quantitative results show that the expected impact on welfare, exports, and domestic production are very small to zero, including for the quota-controlled agricultural products excluded by Canada, Japan, and the United States, as well as textiles and apparel in the latter case.

- Relative to the scenario where only the OECD does so, the large emerging markets do better if they also grant 100 percent DFQF market access to LDCs. 
- Extending DFQF access to other low-income countries (by the World Bank definition) has little impact on existing LDC beneficiaries or preference-giving countries, but big benefits for Pakistan and Vietnam if they are included. ${ }^{28}$

- Extending DFQF to other small and poor (lower middle-income) countries has large benefits in some cases for those countries, but at the expense of existing LDC beneficiaries, especially in Africa, and also entails higher costs for preference-giving countries.

The context around these potential gains is also important, however. In particular, they assume full utilization of available market access, but that does not happen for a number of reasons. It did not happen under the EU's Everything But Arms program in the past because of rules of origin that are highly restrictive in some sectors and prevent LDC exporters being able to take advantage. The value of U.S. and other reforms in the future will also depend on what kind of rules they choose to implement.

Whether African fish and clothing exports respond to the change in EU rules of origin will tell us something about the importance of complementary policies to support full utilization of preference programs. We know that policies outside preference programs themselves, such as sanitary and phyto-sanitary standards ${ }^{29}$ affect agricultural trade in importing countries, and that inadequate infrastructure and excessive red tape in LDCs, are often at least as important as traditional border measures in suppressing LDC exports. Aid for trade and reforms to improve investment climates in the exporting countries need to be addressed before preference programs can reach their full potential.

But providing market access is a step that this analysis suggests would be both beneficial for LDCs, and low-cost for preference-giving countries. UN Secretary General Ban Ki Moon just designated 2010 as the "year of development" and called for accelerated efforts to achieve the Millennium Development Goals. The ongoing economic crisis in many rich countries contributed to rising protectionist pressures in those countries and could make this proposal seem less feasible. But the analysis here underscores the small effects on production in preference-giving countries and the crisis should not be an excuse for delaying achievement of the goal of providing duty-free, quota-free market access for LDCs by rich countries, as well as by Brazil, China, India, and other developing countries "in a position to do so."

\footnotetext{
${ }^{28}$ Note, however, that Pakistan recently moved into the World Bank's low-middle income category and Vietnam is expected to do so, possibly as soon as this year.

${ }^{29}$ Disdier, Fontagné and Mimouni (2004) analyze the impact of sanitary and phyto-sanitary 5SPS) rules, as well as technical barriers to trade(TBT). They show that SPS and TBT have a significant impact on LDCs exports especially from the EU market. Actually they've shown that despite the fact that other OECD countries enforce more SPS rules, those imposed by the EU impede more LDCs exports on agricultural products. Obviously these SPS and TBT rules are often legitimate, but they can also be protectionist.
} 
Annex Table 1: Regions and Sectors Used in the Model

\begin{tabular}{|l|l|}
\hline Regions & Sectors \\
\hline Australia New Zealand & Agrofood (aggregate) \\
Bangladesh* & Animal and meatproducts \\
Bolivia** & Beverage and tobaccoproducts \\
Brazil & Chemicalrubber plastic products \\
Canada & Coal oilgas \\
Central America*** & Cotton woolsilkforestry \\
China & Fish \\
EFTA & Industry (aggregate) \\
Ethiopia* & Leatherproducts \\
EU & Metals \\
India & Milk \\
Indonesia & Oilseeds \\
Japan & Othercereal grains \\
Korea South & Other crops (includes raw tobacco) \\
Madagascar* & Otherfoodproducts \\
Malawi* & Othermanufacturedproducts \\
Mauritius & Otherminerals \\
Mexico & Other services \\
Middle East and North Africa & Rice \\
Mozambique*; & Services \\
Nigeria & Sugar \\
Oil exporting countries & Textile \\
Pakistan & Trade \\
Paraguay* & Transport \\
Philippines & Vegetable and fruit \\
Rest of Africa*** & Vegetableoils and fats \\
Rest of Asia and Oceania & Wearingapparel \\
Rest of Eastern Europe & Wheat \\
Rest of Latin America*** & \\
Rest of South East Asia* & \\
Senegal* & \\
South Africa & \\
Sri Lanka** & \\
Turkey & \\
US & \\
Vietnam & \\
\hline
\end{tabular}

* Least developed countries

** Other small and poor countries

*** Region includes LDCs and/or other small and poor countries 
Annex Table 2: List of sensitive products at the HS6 level, defined from the model of Jean and al. (2010)

(the first 35 products are reported)

\begin{tabular}{|c|c|c|c|c|c|}
\hline \multicolumn{2}{|r|}{ The United States } & \multicolumn{2}{|r|}{ The European Union } & \multicolumn{2}{|r|}{ Canada } \\
\hline hs6 & excluded products & hs6 & excluded products & hs6 & excluded products \\
\hline 240120 & TOBACCO PARTLY OR WHOLLY STEMMED OR STR & 010111 & PURE BRED BREEDING HORSES & 040510 & BUTTER EXCL. DEHYDRATED BUTTER AND GHEE \\
\hline 620520 & MEN'S OR BOYS' SHIRTS OF COTTON EXCL. K & 010119 & LIVE HORSES EXCL. PURE BRED FOR BREEDIN & 040690 & CHEESE EXCL. FRESH CHEESE INCL. WHEY C \\
\hline 240110 & TOBACCO NOT STEMMED OR STRIPPED & 010210 & PURE BRED BREEDING BOVINES & 020714 & FROZEN CUTS AND EDIBLE OFFAL OF FOWLS OF \\
\hline 611020 & JERSEYS PULLOVERS CARDIGANS WAISTCOAT & 010290 & LIVE BOVINE ANIMALS EXCL. PURE BRED FOR & 180690 & CHOCOLATE AND othr PREPARATIONS CONTAIN \\
\hline 611030 & JERSEYS PULLOVERS CARDIGANS WAISTCOAT & 010310 & PURE BRED BREEDING SWINE & 190190 & PREPARATIONS OF FLOUR MEAL STARCH OR M \\
\hline 610910 & T SHIRTS SINGLETS AND othr VESTS OF CO & 010391 & LIVE PURE BRED SWINE WEIGHING inf $50 \mathrm{KG}$ & 230990 & PREPARATIONS OF A KIND USED IN ANIMAL FE \\
\hline 610510 & MEN'S OR BOYS' SHIRTS OF COTTON KNITTED & 010392 & LIVE PURE BRED SWINE WEIGHING SUP 50 KG & 190120 & MIXES AND DOUGHS OF FLOUR MEAL STARCH \\
\hline 620193 & MEN'S OR BOYS' ANORAKS INCL. SKI JACKET & 010410 & LIVE SHEEP & 210690 & FOOD PREPARATIONS N.E.S. \\
\hline 170199 & CANE OR BEET SUGAR AND CHEMICALLY PURE S & 010420 & LIVE GOATS & 611780 & MADE UP CLOTHING ACCESSORIES KNITTED OR \\
\hline 620342 & MEN'S OR BOYS`TROUSERS BIB AND BRACE O & 010511 & LIVE FOWLS OF SPECIES GALLUS DOMESTICUS & 650590 & HATS AND othr HEADGEAR KNITTED OR CROC \\
\hline 610610 & WOMEN`S OR GIRLS` BLOUSES SHIRTS AND SH & 010512 & LIVE DOMESTIC TURKEYS WEIGHING inf $=185 \mathrm{G}$ & 040110 & MILK AND CREAM OF A FAT CONTENT BY WEIGH \\
\hline 620530 & MEN'S OR BOYS' SHIRTS OF MAN MADE FIBRES & 010519 & LIVE DOMESTIC DUCKS GEESE TURKEYS AND & 821192 & KNIVES WITH FIXED BLADES OF BASE METAL \\
\hline 610343 & MEN'S OR BOYS' TROUSERS BIB AND BRACE O & 010592 & LIVE FOWLS OF THE SPECIES GALLUS DOMESTI & 850680 & PRIMARY CELLS AND PRIMARY BATTERIES ELE \\
\hline 620343 & MEN'S OR BOYS' TROUSERS BIB AND BRACE O & 010593 & LIVE FOWLS OF THE SPECIES GALLUS DOMESTI & 020713 & FRESH OR CHILLED CUTS AND EDIBLE OFFAL O \\
\hline 620293 & WOMEN`S OR GIRLS` ANORAKS INCL. SKI JAC & 010599 & LIVE DOMESTIC DUCKS GEESE TURKEYS AND & 232 & PREPARED OR PRESERVED MEAT OR MEAT OFFAL \\
\hline 230990 & PREPARATIONS OF A KIND USED IN ANIMAL FE & 600 & LIVE ANIMALS EXCL. HORSES ASSES MULES & 726 & FRESH OR CHILLED CUTS AND EDIBLE OFFAL O \\
\hline 610832 & WOMEN'S OR GIRLS' NIGHTDRESSES AND PYJAM & 10 & FRESH OR CHILLED BOVINE CARCASES AND HAL & 727 & FROZEN CUTS AND EDIBLE OFFAL OF TURKEYS \\
\hline 620630 & WOMEN'S OR GIRLS` BLOUSES SHIRTS AND SH & 20 & FRESH OR CHILLED BOVINE CUTS UNBONED E & 11 & FRESH OR CHILLED FOWLS OF THE SPECIES GA \\
\hline 611241 & WOMEN'S OR GIRLS` SWIMWEAR OF SYNTHETIC & 020130 & FRESH OR CHILLED BOVINE MEAT BONELESS & 712 & FROZEN FOWLS OF THE SPECIES GALLUS DOMES \\
\hline 620640 & WOMEN'S OR GIRLS` BLOUSES SHIRTS AND SH & 020220 & FROZEN BOVINE CUTS UNBONED EXCL. CARCA & 725 & FROZEN TURKEYS OF THE SPECIES DOMESTICUS \\
\hline 610620 & WOMEN'S OR GIRLS` BLOUSES SHIRTS AND SH & 020230 & BONELESS FROZEN MEAT OF BOVINE ANIMALS & 31 & PREPARED OR PRESERVED MEAT OR OFFAL OF T \\
\hline 610520 & MEN'S OR BOYS' SHIRTS OF MAN MADE FIBRES & 020312 & FRESH OR CHILLED HAMS SHOULDERS AND CUT & 020900 & PIG FAT FREE OF LEAN MEAT AND POULTRY F \\
\hline 621111 & MEN'S OR BOYS` SWIMWEAR EXCL. KNITTED O & 020319 & FRESH OR CHILLED MEAT OF SWINE EXCL. CA & 160220 & PREPARATIONS OF LIVER OF ANY ANIMAL EXC \\
\hline 611130 & BABIES` GARMENTS AND CLOTHING ACCESSORIE & 020322 & FROZEN HAMS SHOULDERS AND CUTS THEREOF & 160100 & SAUSAGES AND SIMILAR PRODUCTS OF MEAT \\
\hline 620920 & BABIES` GARMENTS AND CLOTHING ACCESSORIE & 020329 & FROZEN MEAT OF SWINE EXCL. CARCASES AND & 021090 & MEAT AND EDIBLE OFFAL SALTED IN BRINE \\
\hline 610469 & WOMEN'S OR GIRLS`TROUSERS BIB AND BRAC & 020410 & FRESH OR CHILLED LAMB CARCASES AND $1 / 2 \mathrm{C}$ & 010111 & PURE BRED BREEDING HORSES \\
\hline 620413 & WOMEN`S OR GIRLS`SUITS OF SYNTHETIC FIB & 020421 & FRESH OR CHILLED SHEEP CARCASES AND $1 / 2$ & 010600 & LIVE ANIMALS EXCL. HORSES ASSES MULES \\
\hline 620452 & WOMEN'S OR GIRLS` SKIRTS AND DIVIDED SKI & 020422 & FRESH OR CHILLED CUTS OF SHEEP UNBONED & 020110 & FRESH OR CHILLED BOVINE CARCASES AND HAL \\
\hline 610722 & MEN'S OR BOYS' NIGHTSHIRTS AND PYJAMAS O & 020423 & FRESH OR CHILLED BONELESS CUTS OF SHEEP & 120 & FRESH OR CHILLED BOVINE CUTS UNBONED E \\
\hline 620930 & BABIES` GARMENTS AND CLOTHING ACCESSORIE & 020430 & FROZEN LAMB CARCASES AND $1 / 2$ CARCASES & 020130 & FRESH OR CHILLED BOVINE MEAT BONELESS \\
\hline 620822 & WOMEN'S OR GIRLS' NIGHTDRESSES AND PYJAM & 020441 & FROZEN SHEEP CARCASES AND $1 / 2$ CARCASES & 020210 & FROZEN BOVINE CARCASES AND $1 / 2$ CARCASES \\
\hline 611120 & BABIES` GARMENTS AND CLOTHING ACCESSORIE & 020442 & FROZEN CUTS OF SHEEP UNBONED EXCL. CAR & 020220 & FROZEN BOVINE CUTS UNBONED EXCL. CARCA \\
\hline 620463 & WOMEN'S OR GIRLS`TROUSERS BIB AND BRAC & 020443 & FROZEN BONED CUTS OF SHEEP & 020230 & BONELESS FROZEN MEAT OF BOVINE ANIMALS \\
\hline 620453 & WOMEN'S OR GIRLS`SKIRTS AND DIVIDED SKI & 020450 & FRESH CHILLED OR FROZEN MEAT OF GOATS & 020311 & FRESH OR CHILLED CARCASES AND $1 / 2$ CARCAS \\
\hline 610463 & WOMEN'S OR GIRLS' TROUSERS BIB AND BRAC & 020500 & MEAT OF HORSES ASSES MULES OR HINNIES & 020312 & FRESH OR CHILLED HAMS SHOULDERS AND CUT \\
\hline
\end{tabular}


Annex Table 2 (continued): List of sensitive products at the HS6 level, defined from the model of Jean and al. (2010) (the first 35 products are reported)

\begin{tabular}{|c|c|c|c|c|c|}
\hline \multicolumn{2}{|r|}{ Japan } & \multicolumn{2}{|r|}{ Brazil } & \multicolumn{2}{|r|}{ China } \\
\hline hs6 & excluded products & hs6 & excluded products & hs6 & excluded products \\
\hline 170199 & CANE OR BEET SUGAR AND CHEMICALLY PURE S & 520100 & COTTON NEITHER CARDED NOR COMBED & 271000 & PETROLEUM OILS AND OILS OBTAINED FROM BI \\
\hline 100630 & SEMI MILLED OR WHOLLY MILLED RICE & 240120 & TOBACCO PARTLY OR WHOLLY STEMMED OR STR & 081340 & DRIED PEACHES PEARS PAWPAWS TAMARINDS \\
\hline 030490 & FROZEN FISH MEAT WHETHER OR NOT MINCED & 750210 & NICKEL NOT ALLOYED UNWROUGHT & 151790 & EDIBLE MIXTURES OR PREPARATIONS OF ANIMA \\
\hline 420310 & ITEMS OF CLOTHING OF LEATHER OR COMPOSI & 520300 & COTTON CARDED OR COMBED & 400122 & TECHNICALLY SPECIFIED NATURAL RUBBER `TS \\
\hline 640110 & WATERPROOF FOOTWEAR INCORPORATING A PROT & 410431 & FULL GRAINS AND GRAIN SPLITS & 400121 & SMOKED SHEETS OF NATURAL RUBBER \\
\hline 640610 & UPPERS AND PARTS THEREOF EXCL. STIFFENE & 300390 & $\begin{array}{l}\text { MEDICAMENTS CONSISTING OF TWO OR MORE } \\
\text { CO }\end{array}$ & 151620 & VEGETABLE FATS AND OILS AND THEIR FRACTI \\
\hline 030510 & FISH MEAL FIT FOR HUMAN CONSUMPTION & 410620 & GOAT OR KIDSKIN LEATHER DEHAIRED PREPA & 151590 & FIXED VEGETABLE FATS AND OILS AND THEIR \\
\hline 030410 & FRESH OR CHILLED FILLETS AND othr FISH & 620530 & MEN'S OR BOYS' SHIRTS OF MAN MADE FIBRES & 281820 & ALUMINIUM OXIDE EXCL. ARTIFICIAL CORUND \\
\hline 640699 & PARTS OF FOOTWEAR EXCL. OUTER SOLES AND & 300490 & MEDICAMENTS CONSISTING OF MIXED OR UNMIX & 510529 & WOOL COMBED EXCL. THAT IN FRAGMENTS `O \\
\hline 420340 & CLOTHING ACCESSORIES OF LEATHER OR COMPO & 530310 & JUTE AND othr TEXTILE BAST FIBRES RAW & 852290 & PARTS AND ACCESSORIES OF SOUND REPRODUCI \\
\hline 030374 & FROZEN MACKEREL `SCOMBER SCOMBRUS SCOMB & 847160 & INPUT OR OUTPUT UNITS FOR DIGITAL AUTOMA & 121299 & FRUIT STONES AND KERNELS AND othr VEGET \\
\hline 640192 & WATERPROOF FOOTWEAR COVERING THE ANKLE & 851790 & PARTS OF ELECTRICAL APPARATUS FOR LINE T & 030379 & FROZEN FRESHWATER AND SALTWATER FISH EX \\
\hline 640191 & WATERPROOF FOOTWEAR COVERING THE KNEE W & 611020 & JERSEYS PULLOVERS CARDIGANS WAISTCOAT & 400129 & NATURAL RUBBER IN PRIMARY FORMS OR IN PL \\
\hline 030729 & SCALLOPS INCL. QUEEN SCALLOPS OF THE G & 410439 & BOVINE AND EQUINE LEATHER DEHAIRED PRE & 870324 & MOTOR CARS AND othr MOTOR VEHICLES PRIN \\
\hline 640620 & OUTER SOLES AND HEELS OF RUBBER OR PLAS & 530720 & MULTIPLE `FOLDED` OR CABLED YARN OF JUTE & 190490 & CEREALS IN GRAIN FORM PRE COOKED OR OTH \\
\hline 420330 & BELTS WAISTBELTS AND SHOULDER BELTS OF & 410520 & SHEEP OR LAMBSKIN LEATHER WITHOUT WOOL & 271113 & BUTANES LIQUEFIED EXCL. OF A PURITY OF \\
\hline 420321 & SPECIAL SPORTS GLOVES OF LEATHER OR COM & 030375 & FROZEN DOGFISH AND othr SHARKS & 120740 & SESAMUM SEEDS WHETHER OR NOT BROKEN \\
\hline 640199 & WATERPROOF FOOTWEAR COVERING NEITHER THE & 611030 & JERSEYS PULLOVERS CARDIGANS WAISTCOAT & 271119 & GASEOUS HYDROCARBONS LIQUEFIED N.E.S. \\
\hline 100610 & RICE IN THE HUSK `PADDY`OR ROUGH & 410429 & BOVINE AND EQUINE LEATHER DEHAIRED TAN & 400700 & VULCANIZED RUBBER THREAD AND CORD EXCL. \\
\hline 100620 & HUSKED OR BROWN RICE & 610729 & MEN'S OR BOYS'NIGHTSHIRTS AND PYJAMAS O & 190211 & UNCOOKED PASTA NOT STUFFED OR othrWISE \\
\hline 170191 & REFINED CANE OR BEET SUGAR CONTAINING A & 240110 & TOBACCO NOT STEMMED OR STRIPPED & 200919 & ORANGE JUICE WHETHER OR NOT CONTAINING \\
\hline 170112 & RAW BEET SUGAR EXCL. ADDED FLAVOURING O & 170199 & CANE OR BEET SUGAR AND CHEMICALLY PURE S & 030559 & DRIED FISH SALTED NOT SMOKED EXCL. CO \\
\hline 010310 & PURE BRED BREEDING SWINE & 410612 & GOAT OR KIDSKIN LEATHER DEHAIRED MINER & 330129 & ESSENTIAL OILS WHETHER OR NOT TERPENELE \\
\hline 010410 & LIVE SHEEP & 392530 & SHUTTERS BLINDS INCL. VENETIAN BLINDS & 842649 & MOBILE CRANES AND WORKS TRUCKS FITTED WI \\
\hline 010420 & LIVE GOATS & 610910 & T SHIRTS SINGLETS AND othr VESTS OF CO & 151710 & MARGARINE EXCL. LIQUID \\
\hline 010519 & LIVE DOMESTIC DUCKS GEESE TURKEYS AND & 300320 & MEDICAMENTS CONTAINING ANTIBIOTICS NOT & 810510 & COBALT MATTES AND othr INTERMEDIATE PRO \\
\hline 010599 & LIVE DOMESTIC DUCKS GEESE TURKEYS AND & 620113 & MEN'S OR BOYS' OVERCOATS RAINCOATS CAR & 051191 & PRODUCTS OF FISH OR CRUSTACEANS MOLLUSC \\
\hline 010600 & LIVE ANIMALS EXCL. HORSES ASSES MULES & 610510 & MEN'S OR BOYS`SHIRTS OF COTTON KNITTED & 410512 & SHEEP OR LAMBSKIN LEATHER WITHOUT WOOL \\
\hline 020110 & FRESH OR CHILLED BOVINE CARCASES AND HAL & 640419 & FOOTWEAR WITH OUTER SOLES OF RUBBER OR P & 281830 & ALUMINIL \\
\hline 020120 & FRESH OR CHILLED BOVINE CUTS UNBONED E & 620462 & LS`TROUSERS BIB AND BRAC & 510130 & $\begin{array}{l}\text { CARBONIZED WOOL NEITHER CARDED NOR } \\
\text { COMB }\end{array}$ \\
\hline 020130 & FRESH OR CHILLED BOVINE MEAT BONELESS & 610349 & MEN'S OR BOYS' TROUSERS BIB AND BRACE O & 240220 & CIGARETTES CONTAINING TOBACCO \\
\hline 020210 & FROZEN BOVINE CARCASES AND $1 / 2$ CARCASES & 611212 & TRACK SUITS OF SYNTHETIC FIBRES KNITTED & 030329 & FROZEN SALMONIDAE EXCL. PACIFIC SALMON \\
\hline 020220 & FROZEN BOVINE CUTS UNBONED EXCL. CARCA & 590220 & TYRE CORD FABRIC OF HIGH TENSILE POLYEST & 070490 & FRESH OR CHILLED CABBAGES KOHLRABI KAL \\
\hline
\end{tabular}


Annex Table 2 (continued): List of sensitive products at the HS6 level, defined from the model of Jean and al. (2010) (the first 35 products are reported)

\begin{tabular}{|c|c|c|c|c|c|}
\hline \multicolumn{2}{|r|}{ India } & \multicolumn{2}{|r|}{ Mexico } & \multicolumn{2}{|r|}{ Turkey } \\
\hline hs6 & excluded products & hs6 & excluded products & hs6 & excluded products \\
\hline 080131 & FRESH OR DRIED CASHEW NUTS IN SHELL & 240120 & TOBACCO PARTLY OR WHOLLY STEMMED OR STR & 170111 & RAW CANE SUGAR EXCL. ADDED FLAVOURING O \\
\hline 080620 & DRIED GRAPES & 240110 & TOBACCO NOT STEMMED OR STRIPPED & 240120 & TOBACCO PARTLY OR WHOLLY STEMMED OR STR \\
\hline 071390 & DRIED SHELLED LEGUMINOUS VEGETABLES WH & 611030 & JERSEYS PULLOVERS CARDIGANS WAISTCOAT & 120740 & SESAMUM SEEDS WHETHER OR NOT BROKEN \\
\hline 270900 & PETROLEUM OILS AND OILS OBTAINED FROM BI & 620520 & MEN'S OR BOYS' SHIRTS OF COTTON EXCL. K & 090240 & BLACK FERMENTED TEA AND PARTLY FERMENTED \\
\hline 071310 & DRIED SHELLED PEAS 'PISUM SATIVUM`WHE & 620342 & MEN'S OR BOYS' TROUSERS BIB AND BRACE O & 170310 & CANE MOLASSES RESULTING FROM THE EXTRACT \\
\hline 280920 & PHOSPHORIC ACID AND POLYPHOSPHORIC ACIDS & 610910 & T SHIRTS SINGLETS AND othr VESTS OF CO & 240110 & TOBACCO NOT STEMMED OR STRIPPED \\
\hline 080290 & NUTS FRESH OR DRIED WHETHER OR NOT SHE & 121299 & FRUIT STONES AND KERNELS AND othr VEGET & 100890 & CEREALS EXCL. WHEAT AND MESLIN RYE BA \\
\hline 071339 & DRIED SHELLED BEANS 'VIGNA AND PHASEOLU & 620462 & WOMEN'S OR GIRLS' TROUSERS BIB AND BRAC & 080232 & FRESH OR DRIED WALNUTS SHELLED AND PEEL \\
\hline 071331 & DRIED SHELLED BEANS OF SPECIES `VIGNA M & 630622 & TENTS OF SYNTHETIC FIBRES EXCL. FLY SHE & 240130 & TOBACCO REFUSE \\
\hline 090111 & COFFEE EXCL. ROASTED AND DECAFFEINATED & 620630 & WOMEN'S OR GIRLS`BLOUSES SHIRTS AND SH & 151229 & COTTON SEED OIL AND ITS FRACTIONS WHETH \\
\hline 071320 & DRIED SHELLED CHICKPEAS WHETHER OR NOT & 121190 & PLANTS PARTS OF PLANTS SEEDS AND FRUIT & 200570 & OLIVES PREPARED OR PRESERVED othrWISE \\
\hline 890120 & TANKERS & 650590 & HATS AND othr HEADGEAR KNITTED OR CROC & 120720 & COTTON SEEDS WHETHER OR NOT BROKEN \\
\hline 720449 & WASTE AND SCRAP OF IRON OR STEEL 'ECSC' & 030343 & FROZEN SKIPJACK OR STRIPE BELLIED BONITO & 090930 & CUMIN SEEDS \\
\hline 090240 & BLACK FERMENTED TEA AND PARTLY FERMENTED & 611020 & JERSEYS PULLOVERS CARDIGANS WAISTCOAT & 200799 & JAMS JELLIES MARMALADES PUREES OR PAS \\
\hline 170111 & RAW CANE SUGAR EXCL. ADDED FLAVOURING O & 620193 & MEN`S OR BOYS` ANORAKS INCL. SKI JACKET & 121190 & PLANTS PARTS OF PLANTS SEEDS AND FRUIT \\
\hline 130190 & NATURAL GUMS RESINS GUM RESINS AND BAL & 610510 & MEN'S OR BOYS' SHIRTS OF COTTON KNITTED & 100590 & MAIZE EXCL. SEED \\
\hline 151110 & CRUDE PALM OIL & 030420 & FROZEN FISH FILLETS & 091099 & SPICES N.E.S. EXCL. MIXTURES OF DIFFERE \\
\hline 710310 & PRECIOUS STONES AND SEMI PRECIOUS STONES & 621133 & MEN`S OR BOYS` TRACK SUITS AND othr GAR & 090700 & CLOVES WHOLE FRUIT CLOVES AND STEMS \\
\hline 270799 & OILS AND othr PRODUCTS OF THE DISTILLAT & 620343 & MEN'S OR BOYS`TROUSERS BIB AND BRACE O & 091010 & GINGER \\
\hline 080250 & FRESH OR DRIED PISTACHIOS WHETHER OR NO & 611010 & JERSEYS PULLOVERS CARDIGANS WAISTCOAT & 200811 & GROUND NUTS PREPARED OR PRESERVED N.E.S \\
\hline 151620 & VEGETABLE FATS AND OILS AND THEIR FRACTI & 620113 & MEN'S OR BOYS' OVERCOATS RAINCOATS CAR & 050400 & GUTS BLADDERS AND STOMACHS OF ANIMALS O \\
\hline 151190 & PALM OIL AND ITS FRACTIONS WHETHER OR N & 030342 & FROZEN YELLOWFIN TUNAS & 080290 & NUTS FRESH OR DRIED WHETHER OR NOT SHE \\
\hline 151590 & FIXED VEGETABLE FATS AND OILS AND THEIR & 620293 & WOMEN'S OR GIRLS`ANORAKS INCL. SKI JAC & 121299 & FRUIT STONES AND KERNELS AND othr VEGET \\
\hline 080212 & FRESH OR DRIED ALMONDS SHELLED AND PEEL & 621111 & MEN'S OR BOYS` SWIMWEAR EXCL. KNITTED O & 200580 & SWEETCORN 'ZEA MAYS VAR. SACCHARATA` PR \\
\hline 090700 & CLOVES WHOLE FRUIT CLOVES AND STEMS & 620530 & MEN'S OR BOYS` SHIRTS OF MAN MADE FIBRES & 200899 & FRUIT NUTS AND othr EDIBLE PARTS OF PL \\
\hline 071333 & DRIED SHELLED KIDNEY BEANS `PHASEOLUS V & 610130 & OVERCOATS CAR COATS CAPES CLOAKS ANO & 210690 & FOOD PREPARATIONS N.E.S. \\
\hline 080420 & FRESH OR DRIED FIGS & 620213 & WOMEN'S OR GIRLS` OVERCOATS RAINCOATS & 090610 & CINNAMON AND CINNAMON TREE FLOWERS EXCL \\
\hline 870323 & MOTOR CARS AND othr MOTOR VEHICLES PRIN & 611420 & SPECIAL GARMENTS FOR PROFESSIONAL SPORT & 091030 & TURMERIC 'CURCUMA' \\
\hline 080132 & FRESH OR DRIED CASHEW NUTS SHELLED & 610610 & WOMEN'S OR GIRLS` BLOUSES SHIRTS AND SH & 081090 & KIWIFRUIT TAMARINDS CASHEW APPLES JAC \\
\hline 081310 & DRIED APRICOTS & 030759 & OCTOPUS `OCTOPUS SPP.' FROZEN DRIED S & 090111 & COFFEE EXCL. ROASTED AND DECAFFEINATED \\
\hline 520100 & COTTON NEITHER CARDED NOR COMBED & 160590 & MOLLUSCS AND AQUATIC INVERTEBRATES PREP & 120760 & SAFFLOWER SEEDS WHETHER OR NOT BROKEN \\
\hline 440349 & TROPICAL WOOD SPECIFIED IN THE SUBHEADIN & 621210 & BRASSIERES OF ALL TYPES OF TEXTILE MATER & 071320 & DRIED SHELLED CHICKPEAS WHETHER OR NOT \\
\hline 870390 & MOTOR CARS AND othr VEHICLES PRINCIPALL & 610729 & MEN'S OR BOYS` NIGHTSHIRTS AND PYJAMAS O & 080620 & DRIED GRAPES \\
\hline 090230 & BLACK FERMENTED TEA AND PARTLY FERMENTED & 620690 & WOMEN`S OR GIRLS` BLOUSES SHIRTS AND SH & 081310 & DRIED APRICOTS \\
\hline
\end{tabular}


Annex Table 3: Percentage Change in Total Export Value in 2020 in Selected DFQF Scenarios (see text for scenario definitions)

\begin{tabular}{|c|c|c|c|c|c|}
\hline Region & $\begin{array}{l}97 \% \text { to } L D C \text { from } \\
\text { OECD markets (A) }\end{array}$ & $\begin{array}{l}100 \% \text { to } L D C \text { from OECD } \\
\text { markets (B) }\end{array}$ & $\begin{array}{l}100 \% \text { to } L D C \text { and SVE from } \\
\text { OECD markets (C) }\end{array}$ & $\begin{array}{l}100 \% \text { to LDC from OECD } \\
\text { markets + Emerging (D) }\end{array}$ & $\begin{array}{l}\text { Additionnal scenario } \\
\text { with LICs }\end{array}$ \\
\hline ANZ & 0.00 & -0.01 & 0.01 & -0.02 & -0.04 \\
\hline Bangladesh & 0.06 & 4.16 & 3.46 & 4.82 & 3.38 \\
\hline Bolivia & 0.00 & -0.03 & 3.46 & -0.04 & -0.02 \\
\hline Brazil & 0.00 & -0.03 & -0.12 & 0.00 & -0.07 \\
\hline Canada & 0.00 & -0.01 & 0.00 & -0.01 & -0.02 \\
\hline CAm & 0.00 & 0.14 & 0.83 & 0.14 & -0.02 \\
\hline China & 0.00 & -0.03 & -0.06 & -0.02 & -0.10 \\
\hline EFTA & 0.00 & 0.01 & 0.08 & 0.00 & 0.08 \\
\hline Ethiopia & 0.02 & 1.35 & -0.49 & 2.24 & 0.90 \\
\hline EU & 0.00 & -0.01 & 0.32 & -0.01 & 0.12 \\
\hline India & 0.00 & -0.01 & -0.04 & 0.64 & 0.04 \\
\hline Indonesia & 0.00 & -0.03 & -0.07 & -0.03 & 0.02 \\
\hline Japan & 0.00 & 0.00 & 0.04 & 0.00 & 0.49 \\
\hline Korea South & 0.00 & -0.09 & -0.07 & -0.09 & 0.41 \\
\hline Madagascar & 0.01 & -0.03 & -2.28 & 0.57 & -0.70 \\
\hline Malawi & 0.01 & 12.97 & 4.71 & 13.91 & 11.15 \\
\hline Mauritius & 0.00 & 0.03 & -1.96 & 0.05 & -0.35 \\
\hline Mexico & 0.00 & -0.01 & -0.02 & -0.01 & -0.01 \\
\hline MENA & 0.00 & 0.01 & 3.51 & 0.00 & 0.00 \\
\hline Mozambique & 0.00 & 0.39 & -0.48 & 1.41 & 0.21 \\
\hline Nigeria & 0.00 & 0.01 & 0.03 & -0.13 & 0.03 \\
\hline Oil Xers & 0.00 & 0.00 & 0.01 & 0.00 & 0.03 \\
\hline Pakistan & 0.00 & -0.04 & -0.05 & -0.06 & 11.90 \\
\hline Paraguay & 0.00 & -0.04 & 16.95 & -0.03 & -0.03 \\
\hline Philippines & 0.00 & -0.01 & -0.07 & -0.02 & -0.17 \\
\hline Rest of Africa & 0.00 & 0.08 & 0.49 & 0.22 & 0.29 \\
\hline Rest of $A O$ & 0.00 & 0.00 & 0.00 & 0.01 & 0.08 \\
\hline Rest of EE & 0.00 & 0.00 & 0.12 & 0.01 & 0.10 \\
\hline Rest of LA & 0.00 & -0.05 & 0.78 & -0.04 & -0.07 \\
\hline Rest of SEA & 0.05 & 2.52 & 2.40 & 2.55 & 2.25 \\
\hline Senegal & 0.00 & 1.16 & 0.80 & 9.38 & 1.12 \\
\hline South Africa & 0.00 & 0.02 & -0.02 & 0.03 & 0.04 \\
\hline Sri Lanka & 0.00 & -0.01 & 20.94 & -0.05 & -0.27 \\
\hline Turkey & 0.00 & 0.04 & 0.92 & 0.04 & 0.30 \\
\hline US & 0.00 & 0.03 & 0.13 & 0.04 & 0.04 \\
\hline Vietnam & 0.00 & -0.01 & -0.06 & -0.01 & 18.00 \\
\hline
\end{tabular}


Annex Table 4: Percentage Change in Economy-Wide Variables in 2020 from Implementing 100 percent DFQF for LDCs

\begin{tabular}{|c|c|c|c|c|c|c|c|c|c|c|c|}
\hline \multirow[b]{2}{*}{ Region } & \multicolumn{3}{|c|}{ Value of exports } & \multicolumn{2}{|c|}{ GDP (volume) } & \multicolumn{2}{|c|}{ Real effective XR } & \multicolumn{2}{|c|}{ Terms of trade } & \multicolumn{2}{|c|}{ Welfare } \\
\hline & $\begin{array}{l}\text { OECD } \\
\text { only }\end{array}$ & With & & OECD only & WithEMs & OECD only & WithEMs & OECD only & WithEMs & OECD only & WithEMs \\
\hline Australia New Zealand & & -0.01 & -0.02 & 0.00 & 0.00 & -0.01 & -0.01 & -0.01 & -0.01 & 0.00 & 0.00 \\
\hline Bangladesh & & 4.16 & 4.82 & 0.17 & 0.24 & 0.97 & 1.15 & 0.86 & 1.02 & 0.29 & 0.37 \\
\hline Bolivia & & -0.03 & -0.04 & 0.00 & 0.00 & -0.01 & -0.01 & -0.02 & -0.02 & -0.01 & -0.01 \\
\hline Brazil & & -0.03 & 0.00 & 0.00 & 0.00 & -0.01 & -0.02 & -0.02 & -0.02 & -0.01 & -0.01 \\
\hline Canada & & -0.01 & -0.01 & 0.00 & 0.00 & 0.00 & 0.00 & 0.00 & 0.00 & 0.00 & 0.00 \\
\hline Central America & & 0.14 & 0.14 & 0.00 & 0.00 & 0.04 & 0.04 & 0.04 & 0.04 & 0.01 & 0.01 \\
\hline China & & -0.03 & -0.02 & 0.00 & 0.00 & -0.01 & -0.01 & 0.00 & -0.01 & 0.00 & -0.01 \\
\hline EFTA & & 0.01 & 0.00 & 0.00 & 0.00 & 0.00 & 0.00 & 0.00 & 0.00 & 0.00 & 0.00 \\
\hline Ethiopia & & 1.35 & 2.24 & 0.21 & 0.31 & 0.52 & 0.78 & 0.52 & 0.81 & 0.29 & 0.43 \\
\hline EU & & -0.01 & -0.01 & 0.00 & 0.00 & 0.00 & 0.00 & 0.00 & 0.00 & 0.00 & 0.00 \\
\hline India & & -0.01 & 0.64 & 0.00 & -0.02 & -0.02 & -0.17 & -0.01 & -0.14 & 0.00 & -0.03 \\
\hline Indonesia & & -0.03 & -0.03 & -0.01 & -0.01 & -0.01 & -0.02 & -0.01 & -0.01 & -0.01 & -0.01 \\
\hline Japan & & 0.00 & 0.00 & 0.00 & 0.00 & 0.00 & -0.01 & 0.00 & 0.00 & 0.00 & 0.00 \\
\hline Korea South & & -0.09 & -0.09 & 0.04 & 0.04 & -0.01 & -0.02 & 0.00 & 0.00 & 0.11 & 0.11 \\
\hline Madagascar & & -0.03 & 0.57 & -0.01 & 0.04 & -0.02 & 0.26 & -0.02 & 0.22 & -0.02 & 0.14 \\
\hline Malawi & & 12.97 & 13.91 & 1.21 & 1.40 & 3.80 & 4.26 & 3.98 & 4.44 & 2.65 & 2.99 \\
\hline Mauritius & & 0.03 & 0.05 & 0.01 & 0.01 & 0.01 & 0.01 & 0.01 & 0.02 & 0.02 & 0.02 \\
\hline Mexico & & -0.01 & -0.01 & 0.00 & 0.00 & 0.00 & 0.00 & 0.00 & 0.00 & 0.00 & 0.00 \\
\hline Middle East and North Africa & & 0.01 & 0.00 & 0.00 & 0.00 & 0.00 & 0.00 & 0.00 & 0.00 & 0.00 & 0.00 \\
\hline Mozambique & & 0.39 & 1.41 & 0.15 & 0.41 & 0.17 & 0.67 & 0.17 & 0.61 & 0.17 & 0.52 \\
\hline Nigeria & & 0.01 & -0.13 & 0.00 & -0.05 & 0.00 & -0.05 & 0.00 & -0.08 & 0.00 & -0.11 \\
\hline Oilexporting countries & & 0.00 & 0.00 & 0.00 & 0.00 & 0.00 & 0.00 & 0.00 & 0.00 & 0.00 & 0.00 \\
\hline Pakistan & & -0.04 & -0.06 & 0.00 & -0.01 & -0.02 & -0.03 & -0.01 & -0.02 & 0.00 & -0.01 \\
\hline Paraguay & & -0.04 & -0.03 & -0.02 & -0.01 & -0.02 & -0.02 & -0.02 & -0.02 & -0.03 & -0.03 \\
\hline Philippines & & -0.01 & -0.02 & 0.00 & 0.00 & 0.00 & -0.01 & 0.00 & 0.00 & 0.00 & -0.01 \\
\hline Rest of Africa & & 0.08 & 0.22 & 0.02 & 0.05 & 0.04 & 0.11 & 0.02 & 0.08 & 0.03 & 0.08 \\
\hline Rest of Asia and Oceania & & 0.00 & 0.01 & 0.00 & 0.01 & 0.00 & 0.01 & 0.00 & 0.01 & 0.00 & 0.02 \\
\hline Rest of Eastern Europe & & 0.00 & 0.01 & 0.00 & 0.00 & 0.00 & 0.00 & 0.00 & 0.00 & 0.00 & 0.00 \\
\hline Rest of Latin America & & -0.05 & -0.04 & -0.01 & -0.01 & -0.02 & -0.02 & -0.02 & -0.02 & -0.01 & -0.01 \\
\hline Rest of South East Asia & & 2.52 & 2.55 & 0.42 & 0.43 & 0.77 & 0.79 & 0.52 & 0.53 & 0.95 & 0.97 \\
\hline Senegal & & 1.16 & 9.38 & 0.15 & 0.92 & 0.31 & 2.52 & 0.26 & 2.35 & 0.15 & 1.13 \\
\hline South Africa & & 0.02 & 0.03 & 0.00 & 0.00 & -0.01 & -0.02 & 0.00 & 0.00 & 0.00 & 0.00 \\
\hline Sri Lanka & & -0.01 & -0.05 & 0.00 & -0.01 & -0.01 & -0.02 & 0.00 & -0.01 & 0.00 & -0.01 \\
\hline Turkey & & 0.04 & 0.04 & 0.00 & 0.00 & -0.02 & -0.02 & -0.01 & -0.01 & 0.00 & 0.00 \\
\hline US & & 0.03 & 0.04 & 0.00 & 0.00 & -0.01 & -0.01 & -0.02 & -0.02 & 0.00 & 0.00 \\
\hline Vietnam & & -0.01 & -0.01 & 0.00 & 0.00 & 0.00 & 0.00 & 0.00 & 0.00 & -0.01 & 0.00 \\
\hline
\end{tabular}

$\mathrm{XR}=$ exchange rate; Ems = emerging markets (Brazil, China, India) 
Annex Table 4 (continued): Percentage Change in Economy-Wide Variables in 2020 from Implementing 100 percent DFQF for LDCs

\begin{tabular}{|c|c|c|}
\hline Regions & Import Variation (\%) & Added Value(\%) \\
\hline Australia New Zealand & 0.00 & 0.00 \\
\hline Bangladesh & 3.48 & 0.14 \\
\hline Bolivia & -0.03 & -0.00 \\
\hline Brazil & -0.04 & -0.00 \\
\hline Canada & -0.01 & -0.00 \\
\hline Central America & 0.11 & 0.00 \\
\hline China & -0.02 & -0.00 \\
\hline EFTA & 0.01 & 0.00 \\
\hline Ethiopia & 0.84 & 0.22 \\
\hline EU & 0.00 & 0.00 \\
\hline India & -0.01 & -0.00 \\
\hline Indonesia & -0.03 & -0.00 \\
\hline Japan & 0.00 & -0.00 \\
\hline Korea South & -0.09 & 0.13 \\
\hline Madagascar & -0.03 & -0.00 \\
\hline Malawi & 8.96 & 1.71 \\
\hline Mauritius & 0.02 & 0.00 \\
\hline Mexico & 0.00 & 0.00 \\
\hline Middle East and North Africa & 0.00 & 0.00 \\
\hline Mozambique & 0.35 & 0.14 \\
\hline Nigeria & 0.00 & 0.00 \\
\hline Oilexporting countries & 0.00 & -0.00 \\
\hline Pakistan & -0.02 & -0.00 \\
\hline Paraguay & -0.04 & -0.01 \\
\hline Philippines & -0.01 & -0.00 \\
\hline Rest of Africa & 0.08 & 0.02 \\
\hline Rest of Asia and Oceania & 0.00 & 0.00 \\
\hline Rest of Eastern Europe & 0.00 & 0.00 \\
\hline Rest of Latin America & -0.05 & 0.00 \\
\hline Rest of South East Asia & 3.82 & 0.35 \\
\hline Senegal & 0.59 & 0.16 \\
\hline South Africa & 0.02 & 0.00 \\
\hline Sri Lanka & 0.00 & 0.00 \\
\hline Turkey & 0.03 & 0.00 \\
\hline US & 0.02 & 0.00 \\
\hline Vietnam & 0.00 & 0.00 \\
\hline
\end{tabular}


Annex Table 5: Percentage Change in Export Volume in 2020 When OECD Provides 100\% DFQF

\begin{tabular}{|c|c|c|c|c|c|c|c|}
\hline \multirow[b]{2}{*}{ Sector } & \multicolumn{7}{|c|}{ LDCs } \\
\hline & Bangla & Ethiopia & Madag & Malawi & Mozamb & RoSEA & Senegal \\
\hline Agrofood & 1.99 & 5.79 & 0.03 & 14.16 & 4.12 & -3.54 & 6.47 \\
\hline Industry & 5.01 & -3.11 & -0.06 & -8.46 & -0.64 & 3.33 & -1.05 \\
\hline Animal and meatproducts & -5.58 & -3.03 & 0.16 & -28.10 & -4.03 & -6.20 & -4.24 \\
\hline Beverage and tobacco & -2.01 & 3.90 & 0.04 & -4.55 & -0.32 & -1.88 & -0.32 \\
\hline $\begin{array}{l}\text { Chemicalrubber plastic } \\
\text { products }\end{array}$ & -3.95 & -1.56 & 0.02 & -11.33 & 4.95 & -4.37 & -1.27 \\
\hline Coal oilgas & -5.80 & -0.01 & -0.02 & -5.38 & -0.45 & -2.05 & -0.18 \\
\hline Cotton woolsilkforestry & -4.34 & -0.55 & 0.11 & -24.93 & -3.35 & -2.42 & -1.75 \\
\hline Fish & -1.92 & -0.44 & 0.00 & -7.67 & -0.32 & 2.02 & -0.71 \\
\hline Leatherproducts & -2.47 & -4.68 & 0.26 & -19.35 & -0.88 & -3.98 & -0.13 \\
\hline Metals & -6.64 & -3.17 & 0.06 & -14.70 & -0.71 & -6.34 & -1.48 \\
\hline Milk & 812.46 & 3583.82 & -0.13 & -18.47 & 8.40 & -5.25 & -1.60 \\
\hline Oilseeds & 24.09 & 12.92 & -0.31 & -18.77 & 14.92 & -2.66 & -1.49 \\
\hline Othercereal grains & -1.27 & 2.13 & 0.08 & -15.51 & 3.17 & -2.09 & -2.24 \\
\hline Othercrops & 33.98 & -2.63 & -1.09 & 63.41 & 31.55 & -3.64 & -2.06 \\
\hline Otherfoodproducts & -2.34 & 11.55 & 0.09 & -10.05 & -0.16 & -3.56 & -0.64 \\
\hline Othermanufacturedproducts & -5.17 & -2.72 & 0.04 & -13.60 & -0.37 & -3.50 & -0.76 \\
\hline Otherminerals & -1.26 & -0.75 & 0.01 & -4.59 & -0.10 & -1.02 & -0.30 \\
\hline Other services & -3.60 & -1.78 & 0.04 & -12.38 & -0.48 & -3.62 & -1.06 \\
\hline Rice & 50.16 & -1.24 & 0.47 & -15.12 & -1.19 & -4.54 & -0.56 \\
\hline Services & -3.64 & -1.65 & 0.03 & -10.18 & -0.44 & -3.44 & -0.98 \\
\hline Sugar & -3.16 & 0.20 & 0.67 & -11.63 & -1.13 & -3.83 & -2.43 \\
\hline Textile & 5.52 & 0.82 & -0.32 & -21.07 & -1.81 & 16.13 & -1.50 \\
\hline Trade & -4.16 & -1.77 & 0.01 & -12.04 & -0.31 & -4.08 & -0.93 \\
\hline Transport & -4.17 & -1.45 & 0.02 & -8.76 & -0.34 & -3.04 & -0.80 \\
\hline Vegetable and fruit & 71.00 & -1.48 & 0.17 & -18.87 & -1.22 & -2.84 & -1.57 \\
\hline Vegetableoils and fats & -2.47 & -11.43 & -0.60 & -18.91 & 1.06 & -5.34 & 102.21 \\
\hline Wearingapparel & 8.17 & -2.53 & 0.04 & -18.11 & 0.65 & 19.49 & -1.64 \\
\hline Wheat & -3.39 & -4.23 & 0.00 & -21.46 & 0.00 & -1.37 & 0.00 \\
\hline
\end{tabular}




\section{Annex Table 5 (continued)}

\begin{tabular}{|c|c|c|c|c|c|c|c|c|c|c|c|c|c|c|c|}
\hline \multirow[b]{2}{*}{ Sector } & \multicolumn{15}{|c|}{ Other Developing Countries } \\
\hline & $\begin{array}{l}\text { Bolivi } \\
\text { a } \\
\end{array}$ & $\begin{array}{l}\text { Central } \\
\text { America }\end{array}$ & $\begin{array}{l}\text { Indo- } \\
\text { nesia }\end{array}$ & $\begin{array}{l}\text { Mauri } \\
- \\
\text { tius } \\
\end{array}$ & $\begin{array}{l}\text { Nigeri } \\
\text { a }\end{array}$ & $\begin{array}{l}\text { Pakis- } \\
\tan \end{array}$ & $\begin{array}{l}\text { Para- } \\
\text { guay }\end{array}$ & $\begin{array}{l}\text { Philip- } \\
\text { pines }\end{array}$ & $\begin{array}{l}\text { Restof } \\
\text { Africa }\end{array}$ & $\begin{array}{l}\text { Rest of } \\
\text { E. Asia }\end{array}$ & $\begin{array}{l}\text { Rest of } \\
\text { E.Europ } \\
\mathrm{e}\end{array}$ & $\begin{array}{l}\text { Restof } \\
\text { LatAm. }\end{array}$ & $\begin{array}{l}\text { South } \\
\text { Africa }\end{array}$ & $\begin{array}{l}\text { Sri } \\
\text { Lanka }\end{array}$ & Vietnam \\
\hline Agrofood & -0.12 & -0.26 & -0.23 & 0.16 & 0.12 & -0.09 & -0.09 & -0.55 & 1.18 & -0.18 & 0.00 & -0.23 & 0.08 & -0.01 & -0.07 \\
\hline Industry & 0.03 & 0.32 & 0.00 & -0.01 & 0.00 & -0.06 & 0.06 & 0.01 & -0.02 & 0.01 & 0.00 & 0.05 & 0.01 & -0.01 & 0.00 \\
\hline Animal, meatproducts & 0.04 & -0.19 & 0.02 & -0.54 & -0.04 & 0.16 & 0.25 & 0.11 & 0.83 & 0.27 & -0.14 & 0.14 & 0.11 & 0.04 & -0.07 \\
\hline Beverages, tobacco & 0.02 & -0.09 & 0.51 & -0.01 & 0.01 & 0.02 & 0.04 & 0.02 & -0.08 & 0.20 & 0.00 & 0.03 & 0.04 & 0.03 & 0.17 \\
\hline Chemical, rubber, plastic & 0.05 & 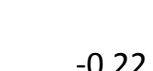 & 0.05 & 0.07 & 0.01 & 006 & 0.04 & 0.09 & -0.09 & 000 & -0.01 & 0.05 & 013 & 006 & 020 \\
\hline Coal, oil, gas & 0.06 & -0.01 & -0.19 & -0.03 & 0.00 & -0.05 & 0.12 & -0.12 & 0.04 & -0.09 & -0.01 & 0.00 & -0.03 & 0.00 & 0.00 \\
\hline Cotton, wool, silk, forestry & -0.01 & 0.03 & 0.12 & -0.20 & 0.50 & 0.60 & 0.08 & 0.09 & -0.52 & -0.03 & 0.35 & 0.25 & 0.09 & 0.08 & -0.05 \\
\hline Fish & 0.05 & -0.09 & 0.01 & 0.01 & 0.00 & 0.02 & 0.04 & 0.10 & -0.02 & 0.02 & 0.00 & 0.02 & -0.03 & 0.03 & 0.08 \\
\hline Leatherproducts & 0.11 & -0.30 & 0.03 & -0.04 & 0.03 & 0.05 & 0.10 & 0.01 & -0.25 & 0.13 & 0.01 & 0.14 & -0.03 & 0.03 & -0.01 \\
\hline Metals & 0.11 & -0.35 & 0.04 & -0.03 & 0.02 & -0.03 & 0.07 & -0.01 & -0.13 & -0.01 & 0.01 & 0.11 & -0.07 & 0.04 & 0.10 \\
\hline Milk & -0.04 & -0.21 & 0.14 & 0.10 & 0.29 & -0.10 & -0.02 & -0.02 & 0.19 & 0.12 & -0.04 & 0.02 & 0.23 & -0.04 & 0.22 \\
\hline Oilseeds & -1.78 & -1.31 & -0.72 & -0.33 & 0.99 & -18.84 & -0.15 & -3.09 & 96.04 & -0.68 & -0.78 & -0.01 & 1.81 & -0.77 & -2.87 \\
\hline Othercereal grains & 0.02 & 0.09 & 0.02 & 0.28 & 0.03 & 0.10 & 0.06 & 0.13 & -0.15 & 0.56 & 0.08 & 0.14 & 0.28 & 0.04 & 0.26 \\
\hline Othercrops & -0.21 & -1.12 & -0.52 & -0.41 & -0.01 & -0.12 & -0.20 & -0.40 & -0.26 & -0.16 & -0.32 & -1.11 & 0.03 & 0.05 & -0.17 \\
\hline Otherfoodproducts & 0.06 & -0.15 & -0.02 & -0.06 & 0.00 & -0.08 & -0.01 & -0.05 & -0.10 & 0.01 & -0.02 & 0.03 & 0.05 & -0.05 & -0.15 \\
\hline Othermfd.products & 0.04 & -0.22 & 0.06 & -0.05 & -0.01 & 0.04 & 0.05 & 0.02 & -0.07 & -0.01 & 0.00 & 0.07 & 0.03 & 0.03 & 0.00 \\
\hline Otherminerals & -0.01 & -0.07 & 0.00 & -0.01 & 0.00 & 0.02 & 0.06 & 0.00 & -0.03 & 0.00 & 0.00 & 0.01 & -0.02 & 0.01 & -0.01 \\
\hline Other services & 0.07 & -0.18 & 0.04 & -0.03 & 0.00 & 0.04 & 0.06 & 0.03 & -0.09 & 0.00 & 0.00 & 0.08 & -0.03 & 0.02 & 0.01 \\
\hline Rice & 0.01 & 0.05 & 0.17 & -0.27 & 0.14 & 0.12 & 0.03 & 0.17 & 0.37 & 0.06 & 0.06 & 0.12 & 0.19 & 0.10 & 0.13 \\
\hline Services & 0.07 & -0.17 & 0.04 & -0.02 & 0.00 & 0.03 & 0.06 & 0.03 & -0.08 & 0.00 & 0.00 & 0.08 & -0.03 & 0.02 & 0.01 \\
\hline Sugar & -0.07 & -0.23 & -0.28 & 0.27 & 0.32 & 0.23 & 0.27 & -0.43 & 0.31 & 0.15 & 0.09 & 0.30 & -0.13 & 0.37 & -0.17 \\
\hline Textile & -0.40 & 4.29 & 0.04 & 0.05 & 0.08 & -0.12 & 0.01 & -0.20 & -0.25 & 0.33 & 0.02 & -0.21 & -0.07 & -0.16 & -0.08 \\
\hline Trade & 0.06 & -0.20 & 0.04 & -0.03 & -0.01 & 0.03 & 0.05 & 0.03 & -0.09 & -0.01 & -0.01 & 0.07 & -0.05 & 0.01 & -0.01 \\
\hline Transport & 0.07 & -0.14 & 0.04 & -0.01 & 0.01 & 0.03 & 0.06 & 0.02 & -0.07 & 0.00 & 0.00 & 0.07 & -0.03 & 0.02 & 0.00 \\
\hline Vegetable, fruit & 0.07 & -0.03 & 0.17 & -0.20 & 0.07 & 0.25 & 0.08 & 0.26 & -0.45 & 0.02 & 0.00 & 0.08 & 0.07 & 0.13 & 0.09 \\
\hline Vegetableoils, fats & -0.02 & -0.64 & -0.43 & 2.18 & -0.15 & -0.46 & -0.24 & -3.75 & -2.05 & -0.99 & -0.77 & -1.13 & 0.48 & -0.14 & 0.43 \\
\hline Wearingapparel & -0.13 & 0.60 & -0.02 & -0.07 & 0.21 & 0.01 & 0.06 & -0.08 & -0.24 & 1.04 & 0.06 & -0.01 & 0.06 & -0.03 & -0.13 \\
\hline Wheat & 0.00 & 0.04 & 0.17 & 0.00 & 0.23 & 0.99 & 0.08 & 0.28 & -0.51 & 0.05 & 0.06 & 0.15 & 0.23 & 0.07 & 0.07 \\
\hline
\end{tabular}




\section{Selected Bibliography}

Berisha-Krasniqi V, Bouët A, Laborde D, and Mevel S. 2008, The Development Promise: Can the Doha Development Agenda Deliver for Least developed Countries? IFPRI Note 14, Washington: International Food Policy Research Institute.

Bora B, Cernat L and Turrini A. 2002, Duty and Quota Free access for LDCs: Further evidence from CGE modeling, Policy issus in international trade and commodities, study series No 14

Bouët A, 2008, The Expected Benefits from Trade Liberalization - Opening the Black box of Global Trade Modeling, Washington DC, IFPRI Food Policy Review 8.

Bouët A, Mishra S. and Roy D,2008,Does Africa trade less than it should and why? The role of market access and domestic factors, IFPRI, December, IFPRI Discussion Paper No. 770.

Bougheas S, Demetriades P. and Morgenroth E. 1998. Infrastructure, Transports Costs and Trade. Journal of International Economics, 47 169-89.

Boumellassa $\mathrm{H}$, Laborde D, and MitaritonnaC, 2009, A consistent picture of the protection across the world in 2004: MAcMapHS6 version 2. IFPRI Discussion Paper 903. Washington: International Food Policy Research Institute.

Brenton P, 2003, Integrating the Least Developed Countries into the World Trading System: the current impact of EU Preferences under Everything But Arms, World Bank Working Paper N²5619, February 2003

Decreux $Y$ and Valin H, 2007, MIRAGE, Updated Version of the Model for Trade Policy Analysis: Focus on Agriculture and Dynamics, CEPII Working Paper, 15, October.

Disdier AC, Fontagné L and Mimouni M. 2008. "The Impact of Regulations on Agricultural Trade: Evidence from the SPS and TBT Agreements," American Journal of Agricultural Economics, American Agricultural Economics Association, vol. 90(2), pages 336-350, 05

Elliott, Kimberly Ann. 2010. Open Markets for the Poorest Countries: Trade Preferences That Work. Report of the Global Trade Preference Reform Working Group. Washington: Center for Global Development.

Elliott, Kimberly Ann. 2009. Opening Markets for Poor Countries: Are We There Yet? Working Paper 184, Washington: Center for Global Development.

Engel J, 2009. Assessing the Chinese and Indian LDC Preference Schemes-Initial Observations. Processed, March.

Fontagne L, Laborde D, and Mitaritonna C. 2008,An Impact Study of the EU-ACP Economic Partnership Agreements (EPAs) in the Six ACP Regions. CEPII Working Paper No. 2008-04. 
Francois J. and Manchin M, 2007,Institutions, Infrastructure and Trade, World Bank Policy Research Working Paper 4152, March 2007

Heckman B, Ng F and Olarreaga M, 2002, Eliminating Excessive Tariffs on exports of Least Developed Countries, The World Bank Economic Review, vol. 16, N 1, 1-21.

Hufbauer, Gary Clyde and Elliott Kimberly Ann, 1994,Measuring the Costs of Protection in the United State, Washington: Institute for International Economics

lanchovichina E, Mattoo A and Olarreaga M, 2001. "Unrestricted Market Access for Sub-Saharan Africa: How Much is it Worth and Who Pays?," CEPR Discussion Papers 2820, C.E.P.R. Discussion Papers

Jean S, David Laborde, and Will Martin, 2010, Formulas and Flexibility in Trade Negotiations: Sensitive Agricultural Products in the World Trade Organization's Doha Agenda. World Bank Economic Review, 24(3): 500-519.

Laborde, D. 2008, Looking for a meaningful Duty Free Quota Free Market Access initiative in the Doha Development Agenda. Issue Paper No. 4. Geneva: International Centre for Trade and Sustainable Development.

Minson A. 2007, Will Chinese Trade Preferences Aid African LDCs? Trade Policy Report No. 19. Johannesburg: South African Institute of International Affairs.

Narayanan B.G., and T.L. Walmsley. 2008. Global Trade, Assistance, and Production: The GTAP 7 Data Base, Center for Global Trade Analysis. Purdue University

Oxfam International. 2005. What Happened in Hong Kong? Initial Analysis of the WTO Ministerial, December 2005. Oxfam Briefing Paper 85.

Portugal-Perez, A. 2007. The cost of rules of origin in apparel: African preferential exports to the United States and the European Union. United Nations Conference on Trade and Development, series study No. 39. Geneva.

Rodrick D, Subramanian A, and Trebbi F. 2004."Institutions Rule: the Primacy of Institutions over Geography and Integration in Trade Development,"Journal of Economic Growth, vol. 9, no. 2 (June).

United Nations. Millennium Declaration (55/2), Resolution adopted by the General Assembly, $18^{\text {th }}$ September 2000.

Vanzetti, David \& Peters, Ralf, 2009. "Duty-free and quota-free market access for LDCs," 2009 Conference (53rd), February 11-13, 2009, Cairns, Australia 47646, Australian Agricultural and Resource Economics Society

World Trade Organization. 2005. Ministerial Declaration, Hong Kong 13-18 December, WT/MIN(05)/DEC. 